\title{
Habent sua fata leges: Glosses, Annotations, and Additions
}

\author{
$1 \quad$ Evidence of the Use of the Weichbild in Legal Practice
}

In Chapter 3, I discussed the content and functions of the modifications introduced into the Weichbild in the course of its transmission through medieval manuscripts until the landmark authorized edition in Jan Łaski's Commune incliti in 1506. The numerous amendations of the received text, be it clarifications or the modifications of individual provisions, were intended to enhance its practical usefulness. This argument finds additional justification in the evidence that Weichbild was being used in the municipal courts. This evidence will be discussed below.

\subsection{Evidence of Legal Practice}

The use of the Weichbild and other regulations in legal practice can be proved not only by analyses of the text evolution and legal practice, but also by broadening the scope of the research to include the hand-written annotations of the users of legal texts. The sources of legal practice, namely, urban records and records of the High Courts of Magdeburg Law in Poland, offer countless examples of the use of the Magdeburg Weichbild, even if a thorough analysis of its application is difficult. The records of legal procedures usually made no precise mention of the provisions upon which the courts of the late medieval Kingdom of Poland based their judgments. Therefore, the link between the court's ruling in any individual case and its legal basis (of which there are many) is always the product of inspired guesswork. Thus, for example, the Wawel MS (BJ 168), which belonged to the High Court of Magdeburg Law at Wawel Castle in Cracow, contained both the Magdeburg Weichbild and the Sachsenspiegel. The judgments of that court from the latter half of the $15^{\text {th }}$ century made only general references to ius Mageburgense and ius Teutonicum, without naming the provision that was being applied. Nonetheless, in some cases, it is possible to establish the link beyond any doubt. So a ruling from 146o ordered the administration of a purgatory oath within the following six weeks in accordance with German law (iuxta formam iuris Teutonici), which corresponds with Article 37 of the Weichbild (cf. Appendix 4). ${ }^{1}$ Article 84 of

1 Decreta I No. 287 from 22 January 146o. Cf. Appendix 2 No. 83 .

(C) MACIEJ MIKUŁA, 2021 | DOI:10.1163/9789004456198_006

This is an open access chapter distributed under the terms of the CC BY-NC 4.o licensęiej Mikuła - 9789004456198 
the Weichbild says that the debtor's property is to be confiscated if he fails to comply with a third order to pay his debt. Exactly this provision was echoed in one of the High Court judgments with the general formula iuris Teutonici iuxta formam. $^{2}$ Similarly, it is a Weichbild provision that requires a purgatory oath of six oath-swearers (metseptimus) in a case of debt clearance, and exactly that requirement can be found in a judgment, issued by the High Court at Wawel Castle from 1462 , which referred to iuris Teutonici iuxta formam. ${ }^{3}$ These are not isolated cases, although it cannot be taken for granted that access to written law was as easy in small towns (little different from bigger villages) as it was in Cracow or towns in their own right. At any rate, the relationship between municipal court judgments and the legal basis of those rulings is a subject worthy of a separate study. Here, I am going to look at another category of evidence which offers material proof of the use of the Weichbild: the hand-written annotations on the extant copies of the Ius municpale Magdeburgense.

\subsection{Types of Paratext in the Latin Texts}

Marginal annotations to Ius municipale offer significant insights into the organization of the text itself, as well as the circumstances of its evolution. Their content is amazingly diverse, ranging from references within the Weichbild through notes, hints, Polish equivalents of Latin terms, indices, and digests, to legal maxims and rules juxtaposed for the sake of comparison. Nevertheless, not all manuscripts are overgrown with the barnacles of notes and commentaries. There are basically no annotations in the Częstochowa ms, the Przemyśl Ms, Mikołaj of Smogorzewo's MS, Q II 157 (2), the Działyńscy Codex IV, the Warsaw Ms, the Opatów Ms, or the Żagań ms. There is a relatively small number of annotations in the St Florian Ms (Flor.), Marcin Zabowski's MS (воZ), and the Kielce MS (Kiel.); and a significant number in MS Q II 157 (1), the St Petersburg MS (F 143), and the Baworowscy (BN 126o7). ${ }^{4}$ A great deal of interesting annotations can be found in the Działyńscy Codex I (Dział. I), Żegota Pauli's MS (BJ 4405), the Leipzig MS (951b), and Tomasz of Bydgoszcz's BN 3068, although not all them are of a later date than the main text. In BN 3068, at least two hands can be distinguished, whereby one of them (A) looks identical to the hand of the main text. Additionally, in the Działyński Codex I (Dział. I), the hand of numerous marginal annotations resembles that of the

2 Decreta I No. 341 from 19 July 1460.

3 Decreta I No. 498 from 20 December 1462.

4 BN 12607 with some German glosses in a hand different the main text, apart from the Latin ones, e.g. in Articles 60 and 61 , the clarification of what belongs to the gerada and the hergewet, respectively. 
main text. In the opening section of that manuscript (up to Article 20), the scripture is small and fine (the glossator uses a distinctive writing instrument and ink), and the annotations to the remaining articles look very much like the hand of the main text, except for one notable difference. Whereas all of the main text is written in a small hand, the letters of the glosses get steadily larger. The uncertainty can eventually be cleared by a close comparison of the two texts. Despite their resemblance, they are the product of two hands. ${ }^{5}$ The same is true of the Żegota Pauli's MS (BJ 4405): the glossator is certainly not the author of the main text. The annotations in copies of Jan Łaski's Statutes need to be dealt with separately. Types of glosses added to the texts of the Weichbild are shown in the Table 22.

TABLE 22 Types of glosses added to the texts of the Weichbild

\begin{tabular}{|c|c|c|c|c|c|c|c|c|c|c|c|c|}
\hline Type of gloss & نี่ & $\underset{\square}{\stackrel{m}{+}}$ & 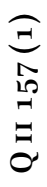 & & $\begin{array}{l}\stackrel{10}{\infty} \\
\stackrel{+}{+} \\
\stackrel{0}{2}\end{array}$ & ON & 这 & $\frac{\ddot{\Xi}}{\vec{I}}$ & 离 & 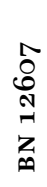 & $\begin{array}{l}\frac{10}{10} \\
\tilde{0}\end{array}$ & $\begin{array}{l}\infty \\
\vdots \\
0 \\
m \\
z\end{array}$ \\
\hline Amendation & + & - & - & + & - & - & - & - & - & - & - & - \\
\hline Reference & - & + & - & - & - & - & - & + & - & + & - & - \\
\hline Index/digest & - & - & + & + & - & + & + & - & - & + & - & + \\
\hline Borrowing from the Cracow version & - & - & - & + & + & - & - & - & - & - & + & - \\
\hline Other supplement & - & - & - & + & - & - & - & - & - & + & - & + \\
\hline Chełmno Law & - & - & - & - & - & - & - & - & - & - & - & - \\
\hline Polish terms & - & - & - & + & - & - & - & - & - & - & + & + \\
\hline Regulae iuris & - & - & - & + & - & - & - & - & - & - & - & + \\
\hline
\end{tabular}

5 Whenever omissions in the base text are corrected by the original scribe, they are introduced as a flagged interlinear gloss in superscript. Other supplements, e.g. regulae iuris or longer passages added by the commentator, neither appear in the form of interlinear glosses, nor are they marked in any way. Only at one point does the scribe insert a manicule to indicate that the regulae copied in the upper margin refer to Article 40, further down the page, and not to the adjacent Article 39 . 


\subsection{Amendations of Errors in the Sandomierz Version}

The later glossator added only a few annotations and amendations to the Gniezno manuscript. As a comparison with other texts of the versio Sandomiriensis shows, they appear beside four articles. The gloss to Article 48 invests the court with the right to make a decision about the hergewet when a nephew claims the right to inherit after his maternal grandfather. ${ }^{6}$ In Article 100, the gloss corrects an evident error: the mulcts imposed on a sottys (Ger. Schultheiß / Lat. scultetus) were to be collected not by him, but by the wójt (Ger. Vogt / Lat. advocatus) who ruled on such cases. ${ }^{7}$ The gloss to Article 105 sets the number of compurgators in claims regarding debt payment at two rather than six; 8 however, that amendation is missing at Article 79. A brief gloss to Article 67 makes its provision clear. ${ }^{9}$ Amendations to Articles 48, 79, 100, and 105 can also be found in the glosses of the Działyńscy Codex I. ${ }^{10}$

Additionally, a reader of the Żegota Pauli's Ms introduced some linguistic corrections into the text. For example, when in Article $5^{2}$ he spotted an error, evidently made by the copyist of the base text, he put a frame around the superfluous conjunction per (which might be regarded as a less intrusive way of signalling a mistake). ${ }^{11} \mathrm{He}$ also filled in the missing words in the date of the second session of the Burggraf's courts (instead of St John's and St Paul's Day St John's in the original manuscript), ${ }^{12}$ and the same amendation as that added by a reader in $\mathrm{Gn}$. is introduced in Article 10o. Corrections of textual errors can also be found in the Leipzig Ms, but, as noted earlier, they were introduced by the copyist of the main text. ${ }^{13}$

\footnotetext{
6 Cf. Appendix 2, No. 106.

7 Cf. ibidem, No. 206.

8 Cf. Chapter 2. Section 4.3.

$9[67]$ Quod si vir, qui pueros habuerit, occisus fuerit, tres aut plures, et si vir unus iudicialiter pro eo inpulsatus fuerit ...

10 The gloss also fills in other missing fragments of Article 14: si moritur vir, hii pueri, qui in hereditate patris sunt, recipiunt bona et non hii, qui exhereditati sunt (No. 41); Article 24: ita si sibi dominus consentire voluerit. Si autem dominus iuraverit tacto sacramento (No. 6o); Article 29: coram iudice et scabinis; Article 53: unus interrogetur ad dicendum, quid ab eo audierint; Article 56: ipsum solus vidi, hoc est in persona propria. Minor amendations can also be found in Article 24, 25 and 53 .

$11\left[5^{2}\right]$... quod per tutorem ipsum querulari opportet, per prolocutorem per sententiam petat ...

12 No. 14.

13 Article 24: si moritur vir, hii pueri, qui in hereditate patris sunt, recipiunt bona et non hii, qui exhereditati sunt (No. 41). Minor amendations can also be found in Article 1, 4, 5, 13, 14, 30, 34 and 40.
} 


\subsection{Cross-references and Registers}

Cross-references to other articles are rare. There are four of them in the Baworowscy Ms, and they refer to matching provisions of the Weichbild. ${ }^{14}$ In the St Petersburg MS, as we have noted in Chapter 1, Section 3.2, they probably refer to the Sachsenspiegel. Among the rather careless entries made by Commentator B in the Baworowcy Ms, there are only two cross-references. ${ }^{15}$ One is attached to Article 50, which deals with guardianship, and refers to Articles 80,72 , and 73 (indicating that the point at issue is the age of the ward). The Działyńscy Codex I has an identical note: de etate pupili iste l $x \times x \mathrm{c}$. Item in provinciali lxxii et lxxiii. It would seem that MS Dzial. I indicates precisely the corresponding provisions of both the Weichbild and the Sachsenspiegel (Ius provinciale). Yet the first cross-reference in the Działyńscy Codex I and Tomasz of Bydgoszcz's MS are really a shot in the dark, as Article LXXX of the Weichbild does not deal with guardianship at all. The second cross-reference in Tomasz of Bydgoszcz's Ms, at Article 70, is concerned with the definition of mulct and points to Sachsenspiegel.

Tomasz of Bydgoszcz's ms contains a large number of indices in the form of marginal glosses. ${ }^{16}$ In the bilingual Żagań Ms, the original indices (regesta) are German; the Latin supplements are a later addition. In the first part of MS Q II 157 (1), some digests are written in the same hand as the main text, while some are in a different hand. The rest of the text is left un-glossed. The main text of the Weichbild in the Baworowscy ms has no original indices. Those that do appear in some articles were introduced by a commentator at a later date. His is also a comment (heading) next to Article 27 Sequntur capitula de vulneribus per totum. This is absolutely pertinent because the following dozen or so articles deal with crimes of assault and wounding. The indices usually form a cluster of at the beginning of an article (they also feature in the general index prefixed to the main text and written in a different hand). Occasionally, however, an article is prefixed with a laconic indication of content or even a singleword 'heading'. ${ }^{17}$ Some articles, which the commentator deemed for some

14 In the ortyl attached to Article 7, concerned with lien, the reference to f. XVII of Book I (i.e. to the Weichbild) should in fact point to f. XVII verso (or in the foliation as we have it now 43v) where there is Article 59 on the subject of lien. Further cross-references appear at Article 22 on f. XXV to Article 9o (insulting a member of the jury); at Article 25 on f. XI to Article 43 and other articles dealing with donations and inheritance; and at Article 86 on of. XXVIII to Article 105 (proof of a debt claim).

15 These are two short notes in Polish concerning judicial procedure.

16 At Articles 2, 4, 5, 6, 7, 9, 12, 20, 23, 24, 25, 26, 38, 39, 46, 47, 49, 51, 56, 57, 61, 65, 69, 73, 74, 75, $81,87,91$, and 100 (numbers according to Gniezno Ms).

17 For example, Article 13 is prefixed with a laconic and pertinent heading 'obligatio'; the first word of Article 17, 'Nemo', is copied as a marginal gloss alongside the main text; a gloss on 
reason to be more important than others, are signposted with a manicule. ${ }^{18} \mathrm{~A}$ smaller number of auxiliary indices can be found in the St Florian $\mathrm{MS},{ }^{19}$ the Działyńscy Codex I ${ }^{20}$ Marcin Zabowski's Ms, ${ }^{21}$ and the Kielce Ms. ${ }^{22}$

\subsection{Borrowings from the Cracow Version}

The manuscripts of the Cracow version have no glosses that would indicate later collation with the Sandomierz version. When such annotations do make their appearance, it is at the stage of copying and preparing 'hybrid' manuscripts, like the St Florian Ms, the Częstochowa Ms, and the Kielce ms. Two manuscripts of the versio Sandomiriensis - the Żegota Pauli's Ms and the Działyńscy Codex I - were collated at a later stage. The case of the Leipzig MS is more complex: in the first part (up to Article 40), the scribe copied the glosses alongside the main text, but then he changed his mind, and in the second part of the manuscript, he incorporated them in the text itself (cf. Chapter 2, Section 3.4). ${ }^{23}$ They include both minor, although often significant, annotations, as well longer passages from the ortyle. A list is presented in Table 23.

The use of the Cracow version in later collations was somewhat erratic. The commentator of the Weichbild from the Działyńscy Codex I made use of the main text, but left out the supplementary material (ortyle). The author of the Leipzig Ms used the Cracow version most extensively. A significant number of those borrowings overlap with Łaski's Commune incliti, but the two texts are not quite identical. A comparison of the provisions of one portion of the Weichbild in the Leipzig Ms with its counterparts in the Statutes and the manuscripts of the Cracow version reveals a telling similarity between the Leipzig Ms and the Żagań Ms. Meanwhile, a comparison of the annotations added to the Żegota Pauli's ms shows that they are similar to the apparatus of the

the upper margin above the text of Article 16 contains its initial phrase 'Quidquid masculus'; Article 14 is signposted with 'Si aliqui pueri fuerint exhereditati'; similarly, the upper margin gloss above Article 20 repeats the initial phrase of the latter 'Quicunque aliquem'.

At Article 43 (requirements to be met by compurgators), 65 (inflicting of grievous bodily harm by assault with batons and sticks), 76 (non-enforcement of gaming debts), 81 (flagrans delictum), 82 (the Burggraf's court), and 86 (debt recovery after the debtor's death).

19 At the article concerning the Jewish oath, the headline annotation De iuramentum iudeorum is written along the edge in the left margin.

20 In the Działyńscy Codex I, the initial lines of Article 100 are copied into a gloss in the upper margin of the page.

21 At Article 10.

22 At Articles 14, 25, 29, 39, 48, and 61.

23 The commentator acted similarly in the case of the Sachsenspiegel, where he incorporated the gloss into the main text of the articles at the beginning of this law book. 
TABLE 23 Borrowings from the Cracow version in Działyńscy Codex I (Dział. I), Żegota Pauli's MS (BJ 4405) and Leipzig Ms (951b)

No. as in $\quad$ MS Dzial. I $\quad$ MS BJ 4405
MS Gn. and

\begin{tabular}{|c|c|c|c|}
\hline [1] No. 2 & - & - & $\begin{array}{l}\text { Et hoc non dimittendo, non ratione } \\
\text { amoris, molestie, ire vel munerum, } \\
\text { sicut eos iuvet Deus et sancti eius. } \\
\text { as in MS II Q } 4 \text { and the Statutes }\end{array}$ \\
\hline$[1]$ No. 3 & $\begin{array}{l}\text { et honorem civitatis } \\
\text { custodire }\end{array}$ & - & - \\
\hline [3] No. 10 & - & - & triginta sex solidis \\
\hline [10] No. $3^{2}$ & - & - & $\begin{array}{l}\text { metseptimus suis vicinis as in } \\
\text { MS BN } 126 \text { o7 but missing in the } \\
\text { Statutes }\end{array}$ \\
\hline [12] No. 35 & - & - & $\begin{array}{l}\text { vel quivis sua sola manu pro } \\
\text { adiutorio ratione homicidii vel } \\
\text { vulneris duellaris, vel mettertius } \\
\text { ad hoc si pro eo cum testibus fuerit } \\
\text { impulsatus. as in the Statutes }\end{array}$ \\
\hline [13] No. 38 & - & - & $\begin{array}{l}\text { Nullus hospes ab alio advena, et } \\
\text { contra, indiget pignus recipere } \\
\text { pro debito recognito. Si autem } \\
\text { ipsum receperit, extunc acquirere } \\
\text { et prosequi prout alter vir iuridice } \\
\text { oportebit, nisi aliter fuisset inter eos } \\
\text { ordinatum verbotenus in contractu. } \\
\text { as in MS BN 126o7, MS II Q 4, and } \\
\text { the Statutes }\end{array}$ \\
\hline [14] No. 44 & - & - & $\begin{array}{l}\text { Sed deservitum parcium et } \\
\text { rationabile debite debeant solvi de } \\
\text { bonis mortui viri pro dotalitio, et } \\
\text { hoc si mulier fuerit dotata pecuniis } \\
\text { in paratis. Si autem dotata fuerit } \\
\text { in hereditate, propria tunc suum } \\
\text { dotalitium pro aliis debitis iure } \\
\text { valeat optinere. Etiam quivis } \\
\text { vir habens mansionem infra } \\
\text { municipale, ille sue conthorali dare } \\
\text { potest pro dotalicio suam propriam } \\
\text { hereditatem, quam in posse habeat } \\
\text { alienandi, et etiam in aliis bonis } \\
\text { mobilibus in quantum voluerit. as } \\
\text { in MS BN } 12607 \text {, Ms II Q } 4 \text {, and } \\
\text { the Statutes }\end{array}$ \\
\hline
\end{tabular}


TABLE 23 Borrowings from the Cracow version (cont.)

\begin{tabular}{|c|c|c|c|}
\hline $\begin{array}{l}\text { No. as in } \\
\text { MS Gn. and } \\
\text { Appendix II }\end{array}$ & Ms Dział. I & MS BJ 4405 & MS 951b \\
\hline [17] No. 46 & $\begin{array}{l}\text { nec mulier sine consensu } \\
\text { viri }\end{array}$ & $\begin{array}{l}\text { nec mulier sine consensu } \\
\text { viri }\end{array}$ & nec mulier sine consensu viri \\
\hline [18] No. 48 & - & - & $\begin{array}{l}\text { sive sit masculi sive femine, } \\
\text { ex paterna et materna } \\
\text { consanguineitate as in MS II Q } 4 \\
\text { and the Statutes }\end{array}$ \\
\hline [18] No. 49 & $\begin{array}{l}\text { inter se dividunt equaliter. } \\
\text { as in } \mathbf{M S ~ I I ~}_{4}\end{array}$ & - & $\begin{array}{l}\text { inter se dividunt equali forma. as } \\
\text { in the Statutes }\end{array}$ \\
\hline [33] No. 75 & - & - & $\begin{array}{l}\text { Ad hoc si ambo in recenti accione } \\
\text { cum clamore ad iudicium fuerint } \\
\text { deducti. as in MS II } \mathbf{Q} 4 \text { and the } \\
\text { Statutes }\end{array}$ \\
\hline [42] No. 95 & - & $\begin{array}{l}\text { In nullus causis precio } \\
\text { conventi seu empti possunt } \\
\text { esse testes, quia iure } \\
\text { possunt eici. as in MS BN } \\
\mathbf{1 2 6}_{\mathbf{2}} \text {, Ms Oss., and MS } \\
\mathbf{I I}_{4}\end{array}$ & - \\
\hline [61] No. 146 & $\begin{array}{l}\text { ita tamen, quod senior } \\
\text { dividit et iunior eligit }\end{array}$ & - & [in the main text] \\
\hline [63] No. 150 & $\begin{array}{l}\text { In omni loco iuris est, } \\
\text { ut iudex et iudicet cum } \\
\text { sentenciis scabinorum. }\end{array}$ & - & [in the main text] \\
\hline [66] No. 156 & $\begin{array}{l}\text { ita quod nulla se trahet ad } \\
\text { hanc infra annum et diem ... } \\
\text { nisi legale inpedimentum } \\
\text { ipse propedierit. as in Ms } \\
\text { Przem. }\end{array}$ & $\begin{array}{l}\text { inventa seu reperta anno et } \\
\text { die fuerit as in MS AJG, MS } \\
\text { Kiel., MS BN 126o7, and } \\
\text { Ms Oss. }\end{array}$ & $\begin{array}{l}\text { [in the main text] } \\
\text { as in MS II Q } 4 \text { and the Statutes }\end{array}$ \\
\hline [76] No. 173 & $\begin{array}{l}\text { Eciam si conqueritur quis de } \\
\text { alio de cibariis preparatis } \\
\text { et coctis, hic propius }[\mathrm{s}] \text { est } \\
\text { obtinere iuramento, quam } \\
\text { ille ipsum evadere possit } \\
\text { iuramento. }\end{array}$ & - & [in the main text] \\
\hline
\end{tabular}


TABLE 23 Borrowings from the Cracow version (cont.)

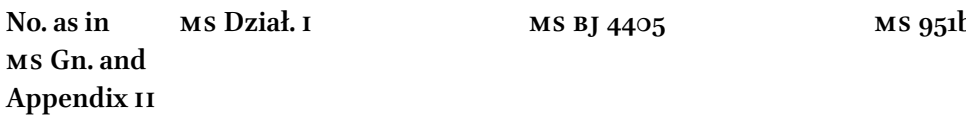

[95] No. $198 \quad-$

[97] No. $200 \quad-$
Consules si iuramentum unius viri receperint, quod secundum iustam sententiam civitatis et statuta consuetudinem exactionem dedisset, et si tunc post mortem illius iurantis plura bona sub ipsius possessione fuerint inuenta, quam exactionata fuisset, illa bona consules non habent recipere, sed ipsius defuncti heredes, nisi aliquis heredum denegata eadem bona coram iudicio vel sedenti consilio recipere abrenunciasset, extunc ipsa bona consulibus pro utilitate civitatis permanent quemadmodum arbitratur seu per arbitrum dimissum est. as in MS BN 12607 and Ms Oss.

Actor etiam reum pro iuramentis promissis causa Dei vel petitionis hominum mittere voluerit absolutum, extunc iudici etiam competit ad hoc dare suam voluntatem, et si suum consensum noluerit adhibere, tunc actorem iuramenta accipere oportebit vel iudici demeretur in pena octo solidorum, et non plus pro causis singulis. as in $\mathbf{M S} \mathbf{B} \mathbf{N}$ 12607 and Ms Oss.

\section{[in the main text]} as in MS II Q 4 but missing in the Statutes

[in the main text] as in the Statutes 
Baworowscy Ms and the Opatów Ms; it is not clear, however, why the glossator of MS BJ 4405 selected certain items rather than others. ${ }^{24}$

\subsection{Additions Made by the Author/Compiler of the Text}

In the text of the manuscripts, we often find additions made by their authors/ compilers. A significant number of these additions can be found in the gloss to the text of the Działyńscy Codex I. These additions typically consist of a word or two, such as, for example, the oath-swearing requirement being extended to the jurors (apart from the judge). ${ }^{25}$ In some cases, the additions are longer, but they do not alter the nature of the regulation, as in Article 105 where the added phrase postulates that the compurgators' rights must not be questioned. This elementary guarantee is repeated in connection with other provisions. Article 2, which deals with the manner in which the town council's decisions concerning trade are to be made public, is expanded with the formula that the announcement should made all over town (in its four corners) as soon as they have been passed. ${ }^{26}$

Article 14 in the Żegota Pauli's Ms is supplemented with the regulation that the dower is excluded from the widow's inheritance, and an extension of Article 45 reaffirms the admissibility of handing over to the wife the goods and chattels bought with money acquired from the sale of heritable property (but the handing over could be done only in court). Moreover, in the upper margin above Articles 1 and 2, there is a partially legible brief note about elder aldermen (consules veteres, see Chapter 3 , Section 2.1.). ${ }^{27}$ Article 100, which deals with the sottys' mulct, is supplemented with a clause obliging a former judge to sojourn in the town where he used to officiate for 50 days after quitting his seat. This requirement was guarantee the efficacy of hearing any complaints

24 See Maciej Mikuła, "Weichbild magdeburski w rękopisie Biblioteki Jagiellońskiej nr 4405” [The Magdeburg Weichbild in MS BJ 4405], in: Nil nisi veritas. Księga dedykowana Profesorowi Jackowi Matuszewskiemu [Nil nisi veritas. A Festschrift Dedicated to Professor Jacek Matuszewski], eds. Marcin Głuszak and Dorota Wiśniewska-Jóźwiak (Łódź, 2016), pp. 151-157.

25 Article 51 and 53.

26 Edicto publico item quatuor anugulos civitatis, si eo arbitro quod civitas ipsa cum senioribus statuit de consensu sue conventis.

27 Consul a consulendo vel a iudicando, nam et hoc consules veteres vocantur ... ad [ $h]$ uc remanet illud rogat bonum consulitis et bonum iudicialis. 
brought against him. ${ }^{28}$ As can be seen from this overview, the range and purpose of the additions varied a great deal. ${ }^{29}$

\subsection{A Comparison of the Provisions of the Weichbild with the Chetmno Law in the Dziatyńscy Codex IV}

The reasons why the author of the Działyńscy Codex IV decided to include in it additional information about the regulations of the Chełmno Law are unknown. In fact, these regulations are not copied verbatim, but made available in the form of summaries and digests. Comparisons with the Chelmno Law are attached to 16 articles in the first part of the text. They are concerned with four points: 1) property relations between spouses; 2) payment of debts; 3) the status of guests (aliens); and 4) procedural issues in criminal cases. Let us consider a few examples.

In Article 14, the author points out that under Chełmno Law, the spouses hold their property jointly, ${ }^{30}$ and the concept of general inheritance (Chapter 3 , Section 4.4) also includes movable goods. ${ }^{31}$ Whereas under Magdeburg Law, the proof of property ownership required the participation of respectable compurgators, namely, property owners who live in the same judicial circuit (Article art. 42), this procedure under Chełmno Law was based first of all on the depositions of jurors or aldermen. Only if one of them died, could his testimony be substituted by that of two property owners. ${ }^{32}$ Debt recovery could not pursued without the participation of jurors, aldermen, an arbiter (in cases of out-of-court settlement), or witnesses of the transaction (Pol. litkupnicy, Lat. iudices mericipotum). ${ }^{33}$ The latter are also mentioned in Article 38 , when the defendant needs to prove that a horse, allegedly stolen, was acquired by him lawfully. Łaski, too, thought it important to retain in his work this extra clause,

28 Quilibet iudex post resignacionem sui officii debet pausare L diebus in eodem loco, ubi tempore officium reposuit, offerens se responsorum omnibus de se querulantibus publiceque sua quevis negocia et non latenter disponere.

29 It may be noted that a gloss to Article 5 in the Baworowscy MS (BN 12607) contains an explanation that one talent (pound) equals 20 szelagi (shillings). Cf. also Note No. 19 in Appendix 2).

$30 \quad$ Article 14: In Colmensi. Dividit uxor cum viro bona per medium, si bona directe ad virum spectant, et e converso.

31 Article 26: In Colmensi. Quicumque mobilia bona ab alto et basso pro bonis hereditariis computantum.

32 Article 42: In Colmensi. Cum scabinis vel consulibus. Si autem mortuifuerint et unus illorum manserit, tunc loco illorum cuiuslibet modum duobus possesionatis, quibus fides adhiberi debet, super proprio probari potest.

33 Article 43: In Colmensi. Cum consulibus, scabinis, arbitris et iudicibus mercipotariis solummodo debitorum probari potest, non aliis hominibus. 
which allows a party accused of acquiring a stolen horse to call in witnesses of the transaction (litkup, festive repast) and thus rebut the charge. ${ }^{34}$ At two points the Działyńscy Codex IV mentions the legal status of guests. The author of the Działyńscy Codex IV writes that to prove their status they need the oath of two compurgators, whereas the Weichbild defines a guest as one whose home is a certain distance away from town, but does not indicate the manner in which this fact is to be established. ${ }^{35}$ In cases of assault where both assailants have inflicted the wounds, the author of the Działyńscy Codex IV says that the party faced with charges in an unfamiliar language should appoint a proxy, whereas according to the Weichbild, the defendant need not respond to the accusation. ${ }^{36}$ In such cases, the Chełmno Law gave the right to precedence in presenting evidence to the party that was first to bring their complaint before the judge or the jurors; according to the Weichbild, that right could be claimed when the complaint was lodged before four jurors, and not the judge in his home. ${ }^{37}$ For the Weichbild, the testimony of the arbiters concerning an outof-court settlement had the same weight as conclusive proof, and the settlement was to be regarded as res iudicata; the regulations of the Chełmno Law were analogous. ${ }^{38}$ The Magdeburg Law set the penalty for a sottys found guilty of violence and house-breaking at 8 shillings; in the Chełmno Law, the corresponding mulct was only half of that sum, as was the penalty for wounding. ${ }^{39}$

The extensive references to the Chełmno law gave rise to conjectures that the Działyńscy Codex IV originated in Wielkopolska or Mazovia, in the vicinity of towns incorporated under that law. However, there is nothing that rules out the other possibility, that is, that the codex was produced in a place nowhere near the Chełmno Law jurisdictions. ${ }^{40}$ We need only to consider the case of the Żegota Pauli's Ms. Its Cracow provenance is beyond doubt, and yet it contains more than a dozen provisions of the Chełmno Law, different from the ones included in the Działyńscy Codex IV (nota bene, Wadowice, a town near

34 Appendix 2, No. 16o.

35 Article 9: Secundum Colmensem mettertius. Cf. Appendix 2, No. 29.

36 Article 28: In Colmensi. Potest per procuratorem sive mundiburdium. Cf. Appendix 2, No. 68. This requirement is missing in the Old Kulm, cf. PS III.4.

37 Article 31: In Colmensi. Qui prius ad iudicium venerit, vel ad scabinos, ille apud Colmensem principium actionis obtinebit. Cf. PS III.17 concerning the priority to be given to a complaint presented to the jurors.

38 Article 23: In Colmensi. Arbitri, quecumque recogo $[v e] r[u] n t$, licet extra iudicium sit concordia facta, vadit in rem iudicatam.

39 Article 5: Pena sculteti in Colmensi quatuor solidi alias XVI quadrantes (cf. PS II.25). Article 22: In Colmensi. Consuli et scabino ferto cuilibet et quod fertones, tot sculteto quatuor solidi.

40 Cf. Chapter 1, Section 3.10. 
Cracow, was founded according to the Chełmno Law; it was an exception in Małopolska). ${ }^{41}$ Moreover, what must not be forgotten in the discussion about the provenance of MS Dzial. IV is the fact that the text of its Weichbild was collated with the manuscript of the High Court of German Law in Cracow. While that filiation points to a Cracow trail in the history of that codex, it is in itself not sufficient to prove or rule out any of the above scenarios.

\section{3}

\section{Polish Equivalents of Latin Legal Terms}

The purpose of including lists of Polish equivalents of Latin terms alongside the text of the law was no doubt practical. ${ }^{42}$ There are two manuscripts which are furnished with more than a fair share of such lists. ${ }^{43}$ The reasons why certain terms rather than others were selected are not clear. It is, however, possible to identify the source used by the glossators, which is a pair of bilingual glossaries, of different length, in the Działyńscy Codex I. ${ }^{44}$ One of them found its way into the St Florian MS, the Przemyśl MS, Jan Wincenty Bandtkie's collection, and Tomasz of Bydgoszcz's ms. So far, due acknowledgement has been made of the texts in ms Dział. I, Ms Flor., and J.W. Bandtkie's collection. ${ }^{45}$ An

41 Stanisław Kuraś, ed., Zbiór dokumentów matopolskich [Collection of Lesser-Poland Documents], 3 (Warszawa, 1969), No. 429 (dated 1430).

42 Friedrich Ebel, Über die Legaldefinitionen. Rechtshistorische Studie zur Entwicklung der Gesetzgebungstechnik in Deutschland, insbesondere über die Verhältnis von Rechtsetzung und Rechtsdarstellung, (Schriften zur Rechtsgeschichte) 6 (Berlin, 1974), p. 42.

43 In the Opatów Ms (Oss.), the Weichbild is glossed with three bilingual terms: satisdatio gwarra (Article 32), rana śmiertelna [fatal wound] (Article 34), and defensorem zachoczcza vel warmana (Article 40). In the Leipzig MS, Article 21 is glossed with a short note: inducias vulgariter rokiy. The introduction of short explanations in the vernacular was common in Latin Europe. Cf. "Section 136. Translations and the Role of the Vernacular Languages in Medieval Europe", in: Translation. An International Encyclopedia of Translation Studies, 2, eds. Harald Kittel, Armin P. Frank, Norbert Freiner, Theo Hermans, Werner Koller, José Lambert, Fritz Paul (Berlin - New York, 2007), p. 1289; Agnieszka Bartoszewicz, Piśmienność mieszczańska w późnośredniowiecznej Polsce [Urban Literacy in Late Medieval Poland] (Warszawa, 2012), pp. 278-279 and Ebel, Über die Legaldefinitionen, p. 40.

44 Secuntur vocabula juris Meydeburgensis (f. 117-122v); Vocabula juris provincialis et feodalis (f. 129r).

45 Joachim Lelewel, "Słownik 87 wyrazów. Vocabula iuris Magdeburgensis koło roku 1455 spisany" [A Glossary of 87 Words - Vocabula iuris Magdeburgensis Written Down c.1455], in: Polska wieków średnich [Medieval Poland], 2nd ed. (Poznań, 1951), pp. 232235; Wacław A. Maciejowski, Historia prawodawstw stowiańskich [History of Slavic Legislatures], 6 (Warszawa, 1858), pp. 409 and 411-412; Zygmunt Celichowski, Stowniczek tacińsko-polski wyrazów prawa magdeburskiego z wieku XV [A Latin-Polish Glossary of 
extended version of these glossaries can be found in Jan Cervus Tucholczyk's Farrago actionum, and especially in Farraginis actionis, ${ }^{46}$ which may be treated as another indication of their usefulness and of a demand which continued well into the 16 th century.

The glossators of the Weichbild in Działyńscy Codex I (Dział. I) and Tomasz of Bydgoszcz's MS (BN 3068) certainly made use of them, as shown by the lists in Table 24. The lexicographic comparison in Table 24 reveals, quite surprisingly,

Magdeburg Law Terms from the 15th Century] (Poznań, 1875); Aleksander Brückner, "Średniowieczne słownictwo prawne" [Medieval Legal Vocabulary], Prace Filologiczne 5 (1895), 35-37; Bolesław Ulanowski, "Opisy rękopisów" [Descriptions of Manuscripts], in: Archiwum Komisji Prawniczej, 2 (Kraków, 1921), pp. XII-XIV; Janusz Sondel, Stownik tacińsko-polski dla prawników i historyków [A Latin-Polish Dictionary for Lawyers and Historians] (Warszawa, 1997), pp. XXV-XXvi; Janusz Sondel, "Ze studiów nad rolą i miejscem łaciny prawniczej w kulturze europejskiej" [Studies on the Role and Position of Legal Latin in European Culture], Krakowskie Studia z Historii Państwa i Prawa 7/1 (2014), 88; Anna Łosowska, Kolekcja Liber legum i jej miejsce w kulturze umystowej późnośredniowiecznego Przemyśla [The Liber legum MS and Its Place in the Intellectual Culture of Late-Medieval Przemyśl] (Warszawa - Przemyśl, 2007), pp. 250-251; Maciej Mikuła, "Niezbędnik średniowiecznego praktyka prawa miejskiego: łacińsko-polski słownik terminów prawnych w rękopisie Biblioteki Narodowej w Warszawie, sygn. 3068 III" [A Necessary Equipment of Municipal Lawyer: Latin-Polish Legal Dictionary in MSS National Library in Warsaw Sign. 3068 III], in: Semper fidelis. Prace dedykowane pamięci Profesora Janusza Sondla legendzie krakowskiego fakultetu prawniczego [Semper fidelis. Works in Honour of Professor Janusz Sondel], eds. Dorota Malec, Łukasz Marzec, Tomasz Palmirski (Kraków, 2017), pp. 273-278.

46 Johannes Cervus Tucholiensis, Farrago actionum juris Magdeburgensis (Cracoviae, 1535), f. 101v-11or; Johannes Cervus Tucholiensis, Farraginis Actionum Iuris Civilis et provincialis, Saxonici, Municipalisq[ue] Maydeburgensis Libri septem..., Book vi (Liber sextus) (Cracoviae, 1546), f. 249-33ov. See Maria Karplukówna, Stownik Jana Cervusa z Tucholi [Johannes Cervus of Tuchola's Glossary] (Wrocław, 1973); Marian Plezia, "Wstęp" [Introduction], Stownik tacińsko-polski [The Latin-Polish Dictionary], 1 (Warszawa, 1959), pp. XII-XIII; Maria R. Mayenowa, Walka o jezzyk w życiu i literaturze staropolskiej [The Struggle for Language in Polish Life and Literature (until the 18th Century)] (Warszawa, 1955), p. 5o, No. 3 (Catalogue of Old Polish Dictionaries); Elżbieta Kędelska, tacińsko-polskie stowniki drukowane pierwszej potowy XVI wieku i ich stosunek do źródet czeskich [Latin-Polish Printed Dictionaries of the Early 16th Century and Czech Sources] (Wrocław, 1986), p. 88ff.; Władysław Bojarski,Jan Jelonek Cervus z Tucholi. Z dziejów prawa rzymskiego w Polsce. Prawo prywatne materialne [Johannes Cervus of Tuchola: A Chapter in the History of Roman Law in Poland. Substantive Private Law] (Toruń, 1989), pp. 45-46; Sondel, Stownik tacińsko-polski, p. xxvi; Janusz Sondel, Z rozważań o tacińsko-polskiej terminologii i leksykografii prawniczej [Reflections on Latin-Polish Legal Terminology and Lexicography], in: Parlament, prawo, ludzie. Studia ofiarowane Profesorowi Juliuszowi Bardachowi [Parliament, the Law and the People: A Festschrift in Honour of Professor Juliusz Bardach], eds. Katarzyna Iwanicka, Maria Skowronek, and Kazimierz Stembrowicz (Warszawa, 1996), p. 272; and Sondel, Ze studiów nad rola i miejscem taciny, p. 88. 
that the explanations in MS BN 3068 do not come from the Vocabula in that manuscript, but from the Vocabula iuris Meydeburgensis known to us from MS Dział. I.

TABLE 24 A list of Latin legal terms and their Polish equivalents including extracts from bilingual glossaries of the Magdeburg Law in Działyńscy Codex I (Dział. I) and the Tomasz of Bydgoszcz's MS (BN 3068)

\begin{tabular}{|c|c|c|c|}
\hline \multicolumn{2}{|l|}{ Gloss text } & \multicolumn{2}{|l|}{ Vocabulary text } \\
\hline Ms Dział. I & MS BN 3068 & Ms Dział. I & MS BN 3068 \\
\hline 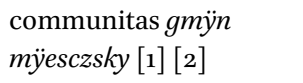 & - & $\begin{array}{l}\text { communitas mÿesczskÿ } \\
\text { gmÿn }\end{array}$ & communitas gmün \\
\hline $\begin{array}{l}\text { arbitrum voluntas } \\
\text { consensus vulgariter } \\
\text { uchwalona wola [1] }\end{array}$ & $\begin{array}{l}\text { arbitrium vel voluntas } \\
\text { consensus uchwala wolna, } \\
\text { alias dicitur wyelkyerz } \\
\text { wsiithkych [1] }\end{array}$ & $\begin{array}{l}\text { arbitrum vel voluntas } \\
\text { consensus alias } \\
\text { uchwalona wola } \\
\text { alias dicitur wilkerz } \\
\text { wsthÿstkych }\end{array}$ & arbitrum vel voluntas \\
\hline $\begin{array}{l}\text { conventus vel consilium } \\
\text { alias gromada } \\
\text { mÿesczka }[1]\end{array}$ & $\begin{array}{l}\text { conventus vel consilium } \\
\text { vulgariter gromada } \\
\text { mieszczka }[1]\end{array}$ & $\begin{array}{l}\text { conventus vel consilium } \\
\text { vulgariter gromada } \\
\text { mÿesczska }\end{array}$ & - \\
\hline$\{$ municipale ius $\}$ & municipale ius vulgariter & municipale ius & municipale ius \\
\hline powÿszschone prawo [1] & powyêszone prawo [1] & powysszone prawo & zawyessone prawo \\
\hline$\{$ Sclavicas marcas $\}$ & Sclavonica marca & Slavica marcis & - \\
\hline slowÿenÿskÿe grzywny [1] & $\begin{array}{l}\text { vulgariter Szlowaczka } \\
\text { grzẏwna [1] }\end{array}$ & Slovienska grzÿwna & \\
\hline $\begin{array}{l}\text { solidus hic videlicet Xii } \\
\text { alenses ... szelag }[1]\end{array}$ & $\begin{array}{l}\text { solidus hic valorem XII } \\
\text { allenseli [1] }\end{array}$ & & - \\
\hline agere conacz [2] & agere vulgariter konacz [3] & agere konacz & - \\
\hline$\{$ decreta\} ustawÿ [2] & $\begin{array}{l}\text { decreta vel statuta } \\
\text { vulgariter ustawÿ [2] }\end{array}$ & $\begin{array}{l}\text { decreta vel statuta } \\
\text { vulgariter ustawÿ }\end{array}$ & - \\
\hline $\begin{array}{l}\text { emenda pokup } \\
\text { emendare pokupÿcz [2] }\end{array}$ & $\begin{array}{l}\text { emenda vulgariter pokup } \\
{[2]}\end{array}$ & emenda pokup & emenda pokup \\
\hline $\begin{array}{l}\text { feriatus dies debet dies } \\
\text { dominicus eclesie dies } \\
\text { naroczÿty dzen [4] }\end{array}$ & $\begin{array}{l}\text { feriatus dies est vulgariter } \\
\text { deicus dies vel celebris et } \\
\text { solemnis dies vulgariter } \\
\text { naroczýsztÿ dzÿen [4] }\end{array}$ & $\begin{array}{l}\text { celebris dies vel } \\
\text { solemnis alias } \\
\text { naroczithy dzyen; } \\
\text { feriatus dies vel } \\
\text { dominicus dies; } \\
\text { in feriato die vel } \\
\text { tempore } w \text { nüedziela abo } \\
\text { naroczütÿ dzen abo czas }\end{array}$ & $\begin{array}{l}\text { dies feriati uroczyszte } \\
\text { szwyatha }\end{array}$ \\
\hline $\begin{array}{l}\{\text { legale impedimentum }\} \\
\text { sprawiedliwa przekarza } \\
\text { vel nagabanÿe [4] }\end{array}$ & $\begin{array}{l}\text { legale impedimentum } \\
\text { vulgariter sprawyedlywa } \\
\text { przekarza vel } \\
\text { nagabanye }[4]\end{array}$ & $\begin{array}{l}\text { legale impedimentum } \\
\text { sprawyedlywa przekarza } \\
\text { vel przegabanÿe }\end{array}$ & $\begin{array}{l}\text { legale impedimentum } \\
\text { przegabane prawa }\end{array}$ \\
\hline
\end{tabular}


TABLE 24 A list of Latin legal terms and their Polish equivalents (cont.)

\begin{tabular}{|c|c|c|c|}
\hline \multicolumn{2}{|l|}{ Gloss text } & \multicolumn{2}{|l|}{ Vocabulary text } \\
\hline Ms Dział. I & MS BN 3 o68 & Ms Dział. I & MS BN 3 o68 \\
\hline- & $\begin{array}{l}\text { sentencia vulgariter } \\
\text { orthel [4] }\end{array}$ & - & sentencia orthyl \\
\hline $\begin{array}{l}\text { talentum rubl et fat xxti } \\
\text { ex argenti pury in sua } \\
\text { summa inhabet loco [3] }\end{array}$ & $\begin{array}{l}\text { talentum vulgariter rubl } \\
\text { et facit xx grossos argenti } \\
\text { puri in sua summa [4] }\end{array}$ & $\begin{array}{l}\text { talentum rubl et facit xx } \\
\text { grossos argenti puri in } \\
\text { sua summa }\end{array}$ & $\begin{array}{l}\text { talentum rubl et facit xxti } \\
\text { solidos denariorum }\end{array}$ \\
\hline $\begin{array}{l}\text { \{irruenciam } \\
\text { domiciliorum }\} \\
\text { uderzenÿe na dom [5] }\end{array}$ & $\begin{array}{l}\text { irruencia domiciliorum } \\
\text { vulgariter uderzenÿe na } \\
\text { dom }[5]\end{array}$ & $\begin{array}{l}\text { irruencia domiciliorum } \\
\text { uderzenÿe na dom }\end{array}$ & - \\
\hline $\begin{array}{l}\text { \{stuprum\} s. odlyeganie } \\
\text { dzewstina }[5]\end{array}$ & - & $\begin{array}{l}\text { stuprum odleegan̈̈e } \\
\text { dziew. }\end{array}$ & stuprum defloracio \\
\hline \{obsidia\} zasadzenÿa [5] & $\begin{array}{l}\text { obsidium vulgariter } \\
\text { zaszadzenye na drodze [5] }\end{array}$ & $\begin{array}{l}\text { obsidium zasadzenÿe na } \\
\text { drodze }\end{array}$ & $\begin{array}{l}\text { obsidium vel } \\
\text { zaszayadzyenye na drodze }\end{array}$ \\
\hline $\begin{array}{l}\{\text { castellani pena et } \\
\text { recompensa\} glowna } \\
\text { zaplata }[5]\end{array}$ & $\begin{array}{l}\text { recompensa vulgariter } \\
\text { glow }[\text { na }] \text { zaplata }[5]\end{array}$ & $\begin{array}{l}\text { recompensa glowna } \\
\text { zaplata }\end{array}$ & $\begin{array}{l}\text { recompensa glowna } \\
\text { zaplata }\end{array}$ \\
\hline- & $\begin{array}{l}\text { temeraria violencia } \\
\text { vulgariter szmýalem } \\
\text { gwattem }[12]\end{array}$ & - & - \\
\hline- & $\begin{array}{l}\text { obligare vulgariter } \\
\text { szastawy [14] }\end{array}$ & $\begin{array}{l}\text { obligat vel inpignorat } \\
\text { zastawya vel zawÿedze }\end{array}$ & - \\
\hline- & $\begin{array}{l}\text { consanguineitatis } \\
\text { vulgariter pokolenya } \\
\text { krewnego [19] }\end{array}$ & $\begin{array}{l}\text { consanguineitas } \\
\text { pokolenÿe krewne }\end{array}$ & - \\
\hline- & $\begin{array}{l}\text { linea vulgariter } \\
\text { kresza }[19]\end{array}$ & linea kresa & - \\
\hline- & 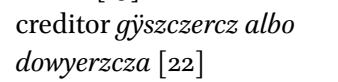 & 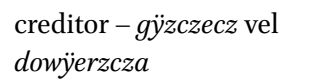 & - \\
\hline- & 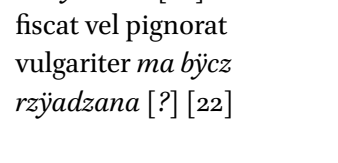 & $\begin{array}{l}\text { fiscata vel iuradicata } \\
\text { zastawyona } \\
\text { fiscatio vel oblicacio est } \\
\text { zastawa }\end{array}$ & $\begin{array}{l}\text { fiscatio eciam vel } \\
\text { oblicacio }\end{array}$ \\
\hline- & 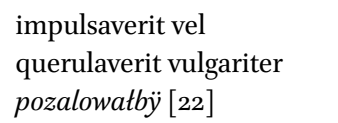 & 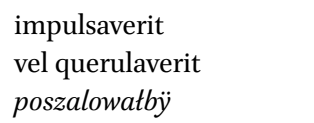 & - \\
\hline- & $\begin{array}{l}\text { sua possessio vulgariter } \\
\text { gyego wladza albo gyego } \\
\text { gymÿenye [22] }\end{array}$ & $\begin{array}{l}\text { sua posessio - gego } \\
\text { wladza albo gÿmüenye }\end{array}$ & - \\
\hline- & $\begin{array}{l}\text { de limina sanctorum } \\
\text { vulgariter poszwÿaczy [23] }\end{array}$ & - & - \\
\hline
\end{tabular}


TABLE 24 A list of Latin legal terms and their Polish equivalents (cont.)

\begin{tabular}{|c|c|c|c|}
\hline \multicolumn{2}{|l|}{ Gloss text } & \multicolumn{2}{|l|}{ Vocabulary text } \\
\hline MS Dział. I & MS BN 3068 & Ms Dział. I & MS BN 3068 \\
\hline- & $\begin{array}{l}\text { paris condicionis et } \\
\text { heredes legittimi natus } \\
\text { secundum formam } \\
\text { Sancte Ecclesie } \\
\text { vulgariter czysthego loza } \\
\text { polozonÿ [29] }\end{array}$ & $\begin{array}{l}\text { paris condicionis vel } \\
\text { heredes legittimi natus } \\
\text { secundum formam } \\
\text { Sancte Ecclesie alias } \\
\text { cistego losza narodzonÿ }\end{array}$ & - \\
\hline- & $\begin{array}{l}\text { pulmentaria vulgariter } \\
\text { jarzy்n̈̈ }[29]\end{array}$ & $\begin{array}{l}\text { pulmentaria vel } \\
\text { legumina vulgariter } \\
\ddot{y} a r z \ddot{y} n \ddot{y}\end{array}$ & - \\
\hline- & 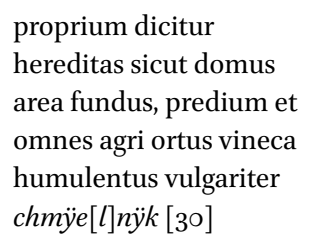 & $\begin{array}{l}\text { proprium dicitur } \\
\text { hereditas sicut domus } \\
\text { area fundus, predium et } \\
\text { omnes agri ortus vinca } \\
\text { et humulentus alias } \\
\text { chmyelnyk }\end{array}$ & - \\
\hline- & $\begin{array}{l}\text { vasa distillatoria szady } \\
\text { spusczadlne }\left[3^{\circ}\right]\end{array}$ & $\begin{array}{l}\text { vasa distillatoria sadj } \\
\text { spusczadlne } \\
\text { - }\end{array}$ & $\begin{array}{l}\text { vasa distillatoria pywne } \\
\text { albo rýnne alias beczky }\end{array}$ \\
\hline- & 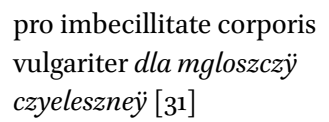 & - & - \\
\hline- & $\begin{array}{l}\text { monomachaliter et } \\
\text { duellatorie vulgariter } \\
\text { szmertelnye [41] }\end{array}$ & $\begin{array}{l}\text { monomachia vel } \\
\text { duellariter smÿertelnyंe }\end{array}$ & $\begin{array}{l}\text { duellum vel mortalitas...; } \\
\text { monomachaliter } \\
\text { szmyerthelnÿe }\end{array}$ \\
\hline- & 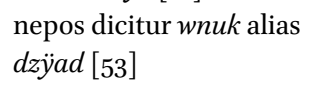 & nepos wnuk & nepos wnuk \\
\hline- & $\begin{array}{l}\text { federa pacis et firmata } \\
\text { pacem vulgariter } \\
\text { sczywierdzony mýr [58] }\end{array}$ & $\begin{array}{l}\text { federa pacis et firmata } \\
\text { pacem vulgariter } \\
\text { sczywyrdzonÿ mür }\end{array}$ & - \\
\hline- & $\begin{array}{l}\text { linea vestimentum } \\
\text { vulgariter parczÿane } \\
\text { dzyenye }[61]\end{array}$ & $\begin{array}{l}\text { linea vestimentum } \\
\text { parczane odzenÿe }\end{array}$ & - \\
\hline- & $\begin{array}{l}\text { hereditas obmortua } \\
\text { vulgariter dzy்edzýna } \\
\text { odumarla albo puscza } \\
\text { przes dzyedzy்cza [71] }\end{array}$ & $\begin{array}{l}\text { hereditas obmortua } \\
\text { dzedzina odumarla } \\
\text { vel pusczina przez } \\
\text { dzyedzicza }\end{array}$ & - \\
\hline- & $\begin{array}{l}\text { refricacio vel } \\
\text { innovacio vulgariter } \\
\text { wsznowyenye }\left[7^{2}\right]\end{array}$ & $\begin{array}{l}\text { refricacio vel invocacio } \\
\text { vulgariter wznowyenye }\end{array}$ & refricare vel innovare \\
\hline $\begin{array}{l}\{\text { mare aquilonis }\} z a \\
\text { morze na polnocz } \ddot{y}[69]\end{array}$ & $\begin{array}{l}\text { ultra mare za morze na } \\
\text { pulnoczy }[74]\end{array}$ & $\begin{array}{l}\text { ultra mare ... za morze } \\
\text { na polnoczÿ }\end{array}$ & \\
\hline
\end{tabular}


TABLE 24 A list of Latin legal terms and their Polish equivalents (cont.)

\begin{tabular}{|c|c|c|c|}
\hline \multicolumn{2}{|l|}{ Gloss text } & \multicolumn{2}{|l|}{ Vocabulary text } \\
\hline Ms Dział. I & MS BN 3 o68 & Ms Dział. I & MS BN 3 o68 \\
\hline- & $\begin{array}{l}\text { vel sub tutorem vulgariter } \\
\text { na zachoczcza albo } \\
\text { splaczcza }[74]\end{array}$ & $\begin{array}{l}\text { tutor vel proloqutor ... } \\
\text { vel eciam zachodzcza } \\
\text { vel splaczcza }\end{array}$ & - \\
\hline- & 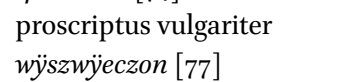 & - & $\begin{array}{l}\text { proscriptus wyrugowany } \\
\text { albo wýszwyeczony }\end{array}$ \\
\hline- & $\begin{array}{l}\text { illiber alias obnoxious } \\
\text { vulgariter nyewolnik alias } \\
\text { vulgariter szuusz [8o] }\end{array}$ & $\begin{array}{l}\text { illiber vel obnoxious } \\
\text { vulgariter szruusz alias } \\
\text { nÿewolnÿk }\end{array}$ & $\begin{array}{l}\text { illiber vel obnoxious } \\
\text { nyewolnyk }\end{array}$ \\
\hline- & $\begin{array}{l}\text { alloquitur vel arrestaverit } \\
\text { vulgariter narzeklby } \\
\text { zasthaw }[89]\end{array}$ & $\begin{array}{l}\text { alloquitur vel } \\
\text { arrestaverit alias } \\
\text { narzeklbÿzasthaw }\end{array}$ & - \\
\hline- & $\begin{array}{l}\text { hereditavit vel dimisit } \\
\text { vulgariter oddzÿelyl od } \\
\text { szyebye [93] }\end{array}$ & - & - \\
\hline
\end{tabular}

Extracts from the text of articles in the Działyńscy Codex I at which the commentator introduced the Polish term without copying it into the gloss are reproduced in curly brackets \{\} .

\section{$4 \quad$ Regulae iuris $^{47}$}

The Regulae iuris, which formed an appendix to Boniface vin's Liber sextus, became widely known in Poland thanks to a popular commentary to the papal code written by Joannes Andreae. ${ }^{48}$ At the end of $15^{\text {th }}$ century, regulae iuris

47 The problem of the presence of regulae iuris in the Weichbild is the subject of detailed analyses in this author's article 'Was Canon Law in Use in Municipal Courts in Late-Medieval Poland? Regulae iuris in Libro sexto in Manuscripts of Municipal Law' (in print). This subchapter is an altered version of that publication.

48 Wacław Uruszczak, "Krakowski komentarz reguł prawa z początku XVI wieku (Lectura super titulo de regulis iuris Libro Sexto)" [A Cracow Commentary on the regulae iuris from the Early 16th Century (Lectura super titulo de regulis iuris Libro Sexto)], Czasopismo Prawno-Historyczne 25/2 (1973), 70, Note 5; Wacław Uruszczak, Regulae Iuris w kulturze prawnej dawnej Polski [Regulae iuris in the Legal Culture of Poland until the 18th Century], Krakowskie Studia Prawnicze 22 (1989), 79-108. Both articles are reprinted in: Wacław Uruszczak, Opera historico-iuridica selecta. Prawo kanoniczne - nauka prawa - prawo 
were even made the subject of a special lecture course at the Faculty of Law at the University of Cracow. ${ }^{49}$ The regulae iuris, or maxims or secondary rules formulated on the basis of existing regulations, were usually employed in legal argument to express in a terse and impressive way certain fundamental principles of law and justice. Collections of regulae iuris of various provenance can be found in the St Petersburg MS (f. 141v-142) and the Działyńscy Codex I. ${ }^{50}$ In Ms Dział. I (f. 239-246) and MS BJ 4405 (f. 5V-9v), they provide the guidelines for the division into groups and the formation of digests of the provisions of the Magdeburg Law.

Some regulae appear as glosses to the Weichbild in the Działyńscy Codex I and Tomasz of Bydgoszcz's ms. Of the 88 regulae in the appendix to Boniface VIII's Liber Sextus, 24 were taken over by the author of Ms Dział. I. He also picked up two more from other sources, ${ }^{51}$ one from the Digesta and one from a treatise Versus de sancto Laurento by Marbodius, Bishop of Rennes. ${ }^{52}$ As not all of them appear in MS BN 3068, a much later work, it can be assumed that the collection in the latter manuscript is secondary. The possible filiation

wyznaniowe [Opera historico-iuridica selecta: Canon Law - Legal Scholarship - Law on Religion], eds. Maciej Mikuła et al. (Kraków, 2017). See also the classic monograph by Peter Stein, Regulae iuris. From Juristic Rules to Legal Maxims (Edinburgh, 1966). Numerous studies of regulae iuris focus mainly on Classical Antiquity and stress the didactic and pragmatic functions of such maxims; see the collection of studies Regulae iuris. Ipotesi di lavoro tra storia e teoria del dirito (Napoli, 2016). There are also studies of the impact of legal rules and maxims in contemporary public discourse, e.g. Agnieszka Kacprzak, Jerzy Krzynówek, and Witold Wołodkiewicz, Regulae iuris: tacińskie inskrypcje na kolumnach Sąu Najwyższego Rzeczypospolitej Polskiej [Regulae iuris: Latin Inscriptions on the Columns of the Supreme Court of the Republic of Poland], ed. Witold Wołodkiewicz (Warszawa, 2001).

49 Wacław Uruszczak, "Wydział Prawa Uniwersytetu Jagiellońskiego i jego profesorowie w latach 1364-1780" [Faculty of Law of the Jagiellonian University and Its Professors in 1364-178o], in: Krzysztof Ożóg, Krzysztof Fokt, Maciej Mikuła, Maciej Zdanek, Dagmara Wójcik-Zega, and Katarzyna Kuras, Profesorowie Wydziału Prawa Uniwersytetu Jagiellońskiego, 1: 1364-1780 [Professors of the Faculty of Law of the Jagiellonian University, 1: 1364-1780], ed. Wacław Uruszczak (Kraków, 2015), pp. XI-XII; Maciej Zdanek, "Jakub z Szadka h. Wieniawa (zm. 28 X 1487)" [Jakub of Szadek (Clan Wieniawa) (d. 28 October 1487)], in: Ożóg et al., Profesorowie Wydziatu Prawa, pp. 106-107.

$5^{\circ}$ This is a short, random collection of regulae (f. 129v).

$5^{1}$ They are given a summary treatment by Johannes Andreae in his Questiones mercuriales super regulae iuris, where he discusses - in addition to the regulae from Liber sextus the regulae from the Digesta (this observation is based on the Venetian edition of the Questiones (Venetiae, 1490)).

$5^{2}$ Jean Jacques Bourassé, eds., Venerabilis Holdeberti primo Cenomanensis episcopi deinde Turonensis archiepiscopo opera omnia, tam edita, quam inedita accesserunt Marboni Redonensis episcopi, ipsius Hildeberti supparis opuscula (Paris, 1854), PL 171:16o8. 
between the two manuscripts is indicated by fairly conclusive evidence that Tomasz of Bydgoszcz, the author of MS BN 3068, made use not only of the Weichbild from Ms Dział. I, but also its Latin-Polish legal glossary. It should be noted though that the regulae added to the Weichbild do not come from the collections from the St Petersburg Ms, the Działyńscy Codex I, or the Żegota Pauli's Ms.

TABLE 25 Regulae iuris in the Weichbild of Działyńscy Codex I (Dział. I) and Tomasz of Bydgoszcz's ms (BN 3068)

1. Actus legitimi conditionem non recipiunt neque diem (50)

2. Adfacinus duplex non sufficit ultio simplex (Marbordius of Rennes)

3. Contra eum qui legem dicere potuit apertius est interpretatio facienda (57)

4. Contractus ex conventione legem accipere diagnoscuntur (85)

5. Cum sunt partium iura reo pocius est faciendum quam [28] actori (11) ${ }^{\mathbf{b}}$

6. Factum legitimum retrotrahi non debet, licet casus postea eveniat a quo non potuit inchoari (73)

7. In pari delicto et causa potior est conditio possidentis (65)

8. In poenis benignior est interpretatio facienda (49)

9. Infamibus porte non pateant dignitarum (87)

10. Inputari ei non debet per quem non stat, si non faciet quod per eum fuerat faciendum (41)

11. Innanis est ex actio, quam excusat inopia debitoris [D.4.3.6]

12. Ius naturale ante omnia obtinet privatum

13. Mutare quis consilium non potest in alterius detrimentum (33) [D.50.17.75]

14. Nemo potest plus iuris conferre, quam sibi competere [22] dignoscatur (79) [D.50.17.54]
[27], [34], [31], [38],

[79]

$[22]$

$[24]^{\mathrm{a}}$

[1]

[24]

[20]

[40]

[1]

[25]

a It should be in Article 25 according to the numbering scheme of MS BN 3068.

b In Liber sextus: Quum sunt partium iura obscura reo fovendum est potius quam actori. 
TABLE 25 Regulae iuris in the Weichbild of Działyńscy Codex I (cont.)

15. Non confirmatur tractu temporis, quoad de iure ab [40] inicio non subsistit (18)

16. Non debet aliquis alterius odio praegravari (22)

17. Non est sine culpa, qui rei quae ad se non pertinet, se immiscet (19)

18. Non praestat impedimentum, quod de iure non sortitur [21] effectum

19. Nullus ex consilio dummodo fraudulentum non fuerit, [1] obligatur (62)

20. Pluralis locutio duorum numero est contenta (40)

21. Possessor male fidei ullo tempore non prescribit (2)

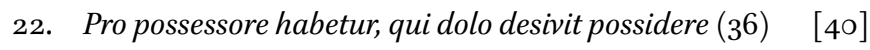
[cf. D.50.17.128]

23. Quod omnes tangit debet ab omnibus approbari $(29)^{\mathrm{d}} \quad$ [1]

24. Quod semel placuit amplius disciplire non potest (21) [1]

25. Scienti et non facienti non est iniuria neque dolus (27) e [28]

26. Semel malus semper presumitur esse malus (8)

27. Successorum naturam sequi congruit principalis $(42)^{\mathrm{f}} \quad$ [40]

c It should be in Article 1.

d Wacław Uruszczak, "Reguła Quod omnes tangit debet ab omnibus approbari dawnego prawa kanonicznego i jej znaczenie" [The Maxim Quod omnes tangit debet ab omnibus approbari in the Old Xanon Law ant its Meaning], in: Servabo legem Tuam in toto corde meo. Ksiega pamiątkowa dedykowana Księdzu Profesorowi Józefowi Krzywdzie CM, Dyrektorowi Instytutu Prawa Kanonicznego UPJPII z okazji 7o. rocznicy urodzin [Servabo legem Tuam in toto corde meo. A Festschrift in Honour of Professor Józef Krzywda см, Manager of the Canon Law Institute of Pontifical University of John Paul II, on His 7oth Birthday], eds. Arkadiusz Zakręta CM, Andrzej Sosnowski CR (Kraków, 2013), pp. 545-559. The article is reprinted in: Wacław Uruszczak, Opera historico-iuridica selecta. On legislative assemblies, see Krystyna Kamińska, "Communitas civium w miastach polskich rządzących się prawem magdeburskim", Acta Universitatis Nicolai Copernici. Prawo 30 (1990), 25-37; Maciej Mikuła, Prawodawstwo króla $i$ sejmu dla matopolskich miast królewskich (1386-1572). Studium z dziejów rządów prawa w Polsce [Royal and Parliamentary Legislation for the Royal Towns of Małopolska (1386-1572): A Study in the History of the Rule of Law in Poland] (Kraków, 2014), pp. 208-215.

e In Liber Sextus: Scienti et consentienti non fit iniuria neque dolus.

f In Liber Sextus: Accessorium naturam sequi congruit principalis.

In round brackets the number of the regula in the standard version of Regularum iuris appended to Boniface viII's Liber sextus.

Table 25 is an expanded version of a table of regulae iuris in my article "Was Canon Law in Use in Municipal Courts in Late-Medieval Poland?" 
On the whole, the regulae were adopted by the authors of the manuscripts to reinforce provisions concerning urban legislation, private law, and procedural and criminal law. Let us turn to a few examples of their application. ${ }^{53}$ The maxim Quod omnes tangit (No. 23 above) is applied to urban by-laws, which, since they concern all, have to be approved by all. Once passed, they must not be changed, nor can those who approved them say that they are not bound them (No. 4 and No. 24). The law must not be altered to serve a malicious intent of doing harm to any particular person (No. 13). Statutes that are adopted fraudulently are invalid (No. 19). The maxim Nullus ex consilio dummodo fraudulentum non fuerit, obligatur appears next to a stipulative statement, characteristic of Konrad of Sandomierz's translation, that urban statutes are binding as long as they conform to God's law. It is doubtlessly a good match.

A number of maxims were added to Article 40, which is concerned with disputed inheritance. According to the Magdeburg Law, if somebody can prove he has held a disputed property in peaceable possession for a year and a day, the court should rule in his favour. This provision is complemented with a pair of maxims - one stating that only a possessor in bad faith cannot benefit from the limitation (prescription) period (No. 21), and the other insisting that an unlawful acquisition will not be made legal by the passage of time (No. 15). Furthermore, the unlawful deprivation of possession was not effective (No. 22). The maxim Ius naturale ante omnia obtinet privatum (No. 12) complements that part of the provision which insists that cum inpossibile sit aliquem de naturali porcione defraudari. ${ }^{54}$ Of the three maxims at Article 79, only one is directly relevant to its interpretation: Pluralis locucio duorum numero est contenta - any plural reference includes two (No. 20). Article 79 deals with proof in action for the recovery of debt in which the plaintiff was expected to produce witnesses, the (minimum) number of which is not specified: Si vir conqueritur super alterum pro suo debito cum testibus, hoc bene potest optinere cum viris fidedignis. In this case, the regula provides the necessary clarification - two are enough. What the other two maxims (Nos. 1 and 6) add to the meaning of Article 79 is hard to make out.

The offence of insulting a member of the jury is addressed in Article 22. Here, too, of the three regulae, two (Nos. 3 and 14) are only loosely connected with the subject, even if they are not quite irrelevant. However, the remaining one - Ad facinus duplex non sufficit ultio simplex (i.e. for double crime, a single penalty is not enough) - is crucial for sentencing a defendant charged with

53 For an in-depth analysis, see ibidem.
54 Cf. Appendix 2, No. 91. 
a qualified offence (contempt of the authority represented by the juryman). Article 39 is concerned with the punishment of theft. In general, the penalties for theft depend on the value of stolen goods. For stealing goods worth less than three shillings, the culprit faced punishment in skin and hair (branding); stealing anything worth more than that that amount was punishable by death (hanging). ${ }^{55}$ In this context, the maxim Semel malus semper presumitur esse malus (i.e. who does wrong once is presumed to be a wrongdoer always) reads like an instruction on how to treat repeat offenders.

In general, from the cases discussed above, we get a sense of an intelligent mind who set himself the task of matching the universal and rather abstract regulae iuris with the detailed, narrowly focused regulations of the Weichbild, even if occasionally the connection between the two is not obvious. These commentators most likely gained their legal expertise at an ecclesiastical court and/or had an academic background. Certainly, their idea of expanding the gloss represents a new trend in the legal culture of late-medieval Poland. ${ }^{56}$ The author of MS BN 12607 was also familiar with the regulae and decided to add one to Article 6 in his text: Summa iuris actus legit cum condicione non recipiunt neque diem, a slightly altered version of Rule No. 1 from Table 25. Weichbild's Medieval Conventions

\subsection{Copies with Few or No Annotations}

A number of copies of taski's Statutes examined in the course of this project do not contain a glossed Weichbild (or, in some cases, a glossed Sachsenspiegel). The gloss is missing in printed copies of the Statutes retained in the Jagiellonian Library, ${ }^{57}$ the National Library in Warsaw, ${ }^{58}$ the University of Wrocław Library, ${ }^{59}$ the National Museum in Cracow, ${ }^{60}$ and the Ossoliński National Institute. ${ }^{61}$ In the copy held by the University of Warsaw Library,

55 Cf. Appendix 2, No. 84, 85 and 86.

56 Uruszczak, "Regulae Iuris w kulturze", p. 79.

57 Shelfmark St. Dr. Cim. 8oo8, a copy dated 1638 , according to S. Wieczorkowski's catalogue; according to another provenance note, it belonged to Collegium Maioris of the University of Cracow. It is heavily annotated (especially the Summa legum by Raymundus Parthenopaeus), but it does not comprise the source texts German law. St. Dr. Cim. 8oog: Summa legum only; St. Dr. Cim. 51 one folium (print).

58 Stare druki (Early Printed Books): Shelfmarks No. 88, 211, 335, 35 o and 735.

59 University of Wrocław Library, Shelfmark St. Dr. 401097.

6o National Museum in Cracow, Shelfmark MNK VIII-XVI.134.

61 Ossoliński National Institute, Shelfmark Xvi.F.4654. 
the Weichbild has no gloss, but the articles of the Sachsenspiegel have been given numbers following the scheme in Mikołaj Jaskier's edition and complemented with a gloss of six short commentaries in the same hand. ${ }^{62}$ One marginal gloss (De proprietate) appears in the Sachsenspiegel in one of the copies held in the Ossoliński National Institute, ${ }^{63}$ and two brief glosses are in one of the copies in the National Library. ${ }^{64}$ In the codex which used to belong to Antoni Zygmunt Helcel, the Weichbild is signposted with a few manicules at the articles on guardianship and deposit. More signs of this kind can be found in the Sachsenspiegel, and there is a longer gloss at the provision concerning the election of jurors according to the Lübeck Law. More annotations, some of them Polish (e.g. the direction czÿtä̈ to 'read this') appear next to the text of Summa legum by Raymundus Parthenopaeus. The glosses in that copy of the Statutes are in at least two hands. ${ }^{65}$ The codex which is now retained by the Juliusz Słowacki Public Library at Tarnów contains two annotations. One is attached to the article on the hergewet in the Weichbild; the other, added to the Sachsenspiegel, is unrelated to the Weichbild. The former is a mere heading providing information on the subject of the article. The latter is a reader's comment on the imprecise preface to the article (the rubric says that it is De armis bellicis, ad quem devoluntur per successionem. Item de tutore puerorum, whereas it deals as well with the gerada). ${ }^{66}$ The copy retained in The Princes Czartoryski Library in Cracow had had a number of blank pages that were filled with excerpts from the land law and a list of Poland's senatorial offices. ${ }^{67}$ Its Weichbild contains a number of glosses which are no more than headings and a pair of cross-references between Articles 79 and 105, which deal with the payment of debts of a deceased relative. Moreover, someone has written on one of the blank pages a Magdeburg ortyl addressed to the Cracow City Council entitled Questiones de Cracovia in Meydburg pro iure misse questio prima.

\subsection{The Weichbild's Adaptation to Polish Realities (Jagiellonian Library, St. Dr. Cim. 80o2-8003)}

Probably soon after its publication, the commentator of this copy of the Statutes (Jagiellonian Library, St. Dr. Cim. 80o2-80o3) supplemented the text

\footnotetext{
62 Shelfmark BUW Sd.612.523. Annotations: Book I, art. 6, 14, 25, 64; Book II, art. 44 i 62.

63 Shelfmark XVI.F.4320, f. 202v.

64 Shelfmark SD XVI.F.337, Article 38: Quis potest esse testis (f. 181v), and also an entry on f. 182. The annotations to articles of the Sachsenspiegel - f. 200 (the Polish gloss), 225, 232, and 242.

65 Jagiellonian Library St. Dr. Cim. 8470.

66 Juliusz Słowacki Public Library at Tarnów, Shelfmark SD 173.

67 Princes Czartoryski Library in Cracow, Shelfmark 30 III Cim.
} 
with a number of annotations so that its Polish readers would find it easier to use. His glosses provide detailed information about the content of individual articles. Therefore, for instance, a marginal gloss to Article 1 about aldermen and jurors describes the competences of the aldermen, including the right to convene an assembly of burghers (consulum est facere conventum sive gromode vulgariter), ${ }^{68}$ and mentions the penalties for aldermen who fail to turn up. One of the practical problems faced by the glossator was the adaptation of the offices mentioned in the Weichbild to Polish realities. In his comment on Article 5, which mentions the courts of the Castellan, the Burggraf, and the Schultheiß (sottys, scultetus), he explains that those terms refer to the owner of the domain, the wójt (advocatus), and podwójci (vice-advocatus), respectively; he also adds a cross-reference to the Constitution of Courts [Rechtsbuch von der Gerichtsverfassung] on f. 196. Consequently, the gloss to Article 6, which sets the time for the three annual rounds of the court called by the Schultheiß/ sottys, explains that the regulation refers to the wójt's court. A brief note next to Article 9 provides information about its content (ius hospitum). In Article 19 (in the Statutes numbering) on deathbed gifts and in Articles 56 and 67 on the duties of guardians, the commentator merely underlined the key phrases in the text of the provisions. ${ }^{69}$

\subsection{References and Digests (Partly Post-1535) (Jagiellonian Library, St. Dr. Cim. 8004-8005)}

The most profusely annotated Weichbild is part of a copy of the Statutes owned in 1584 by the Cracow captain (podstarości, vice-capitaneus) Józef Kowalowski. ${ }^{70}$ Another characteristic of this book is the complete lack of annotations in the texts of the land law, a notable contrast to the heavily glossed Weichbild, Sachsenspiegel, and Master Raymundus' Summa legum. The commentaries are the work of various hands, although most of the annotations to the Weichbild and the Summa legum, as well as the gloss of the Sachsenspiegel, is definitely in one hand (Commentator A). The same glossator also marked

68 The Polish term gromada (here: assembly) is used in the same place in the text by the commentator of the Działyńscy Codex I.

69 Similar annotations can be found in two articles of the Sachsenspiegel, f. 199v and f. 214v.

70 Józef Kowalowski held a number of offices, including the deputy starost of Biecz, deputy starost of Cracow, and deputy judge of the Cracow land court. See Irena Kaniewska, "Kowalowski Józef", in: Polski Stownik Biograficzny [Dictionary of Polish Biography], 14 (Wrocław, 1968-1969), p. 532. The following provenance entry dated 1656 names Marcin Olbrychtowic as owner of this book. See Marian Malicki, Ewa Zwinogrodzka, eds., Marian Malicki, Małgorzata Gołuszka, Wanda Ptak-Korbiel, Zofia Wawrykiewicz, Ewa Zwinogrodzka, coop., Katalog poloników XVI wieku Biblioteki Jagiellońskiej [Catalogue of Polonica from 16th Century in Jagiellonian Library], 1: A-Ł (Kraków, 1992), p. 426. 
articles concerned with usucaption and disinheritance in the digest to the Summa legum, whereas the annotations to digests of source texts of municipal law are in two other hands. Entries in hand A are concentrated around the articles at the beginning of Weichbild, and there are few of them elsewhere. In some cases, Commentator A tries to draw a general conclusion from a rather specific regulation. ${ }^{71}$ Two articles are glossed with cautionary notes that the regulations contained in them were condemned by Pope Gregory XI in his Articuli reprobati; ${ }^{72}$ some articles are cross-referenced or supplemented with references to Master Raymundus' Summa legum..$^{73}$ Most often, however, the annotations merely highlighted the most important points of an article, ${ }^{74}$ either by underlining the key phrases in the main text or copying them in the margin..$^{75}$ The annotations in hand B are intended to help the reader find his way through pages crammed tight with print: they are merely headline glosses with information about the subject of the adjacent passage (e.g. testes, qui non possunt fieri next to the Article 'De vulnerante aliquem' [Art. 38 in the Statutes numbering]).

The text of a reference at Article 2, Spe. Sax. Juri municip [al]ii Art. 44 et 19, makes it possible to date the commentary in hand A. The reference itself is misleading (probably a scribal error), for the relevant Articles 44 and 19 the concerning measures and weights were to be found in the Weichbild rather than the Sachsenspiegel. The commentator seems to have noticed this, but what makes this slip all the more puzzling is the fact that the numbers fit the

$71 \quad$ For example, Probus homo propior evadere (Article 8 'Accusatus de conflicto', f. CLXXVIII); Cause sine mora iudicandi hospiti (Article 9 'De iudicio', f. ClXXVIII); Prescriptio possessionis Annus et dies (Article 17 'De re possessa', f. CLXXIX); Equalis divisio fratribus cum sororibus (Article 20 'De hereditate', f. CLXXIX); and Tres solidi sex grossos valent (Article 46 'De fure diei et noctis', f. CLXXXII verso).

72 The note about Gregory XI's Articuli reprobati: Articulus iste est reprobatus Sp. Sax Art. LII lib primo is inscribed next to Article 15 'De pueris', f. CLXXIX) and his Reprobatus Articulus Spe Sax lib I Ar. LII next to Article 19 'De legationibus', f. CLXXIX).

73 Spe. Sax.Juri municipii Art. 44 et 19 (Article 2 'De penesticis', f. CLXXvil recto); Rajmundus fol. 23, Exhereditatio Spec Sax lib I Ar. 17 At. 14.

74 For example, Divisio scabinorum cum consulibus eligendi; Rota iuramentum scabinorum; Pena 36 solidi; Consulum potestas iudicandi; Inobediens cum nemine neglexerit penam deme[retur] (Article I'De electione', f. CLCcVI verso and CLXXVII recto); Penestici dicuntur; De venditore; Pena eorum si modum excesserit (Article 2 'De penesticis', f. CLXXVII recto); Testimonium vulnerorum; Evictio; Solidorum computacio; In defectu evictori; Recompensa in emenda iudici (Article 7 'De iudicio', f. CLXXVII verso and CLXXVIII); Contumatio actori racione vulnerum (Article 10 'De pernocrato vulnere'); Probatio possessionis (Article 18 'De re possessa', f. CLXXIX).

75 'Prologus in ius Maydemburgense', i.e. ten copied extracts (f. CLXXVI recto i verso); Pro vulnere manum, pro homicidio collum (Article 7 'De iudicio', f. CLXXVII verso). 
Weichbild in Mikołaj Jaskier's Ius Municipale of 1535 (Article 19 on f. 19r and 19v and Article 44 on f. $38 \mathrm{v}$ and ff.).

\subsection{A Glossary of Legal Terms (Post-1531) (National Library in Warsaw, Shelfmark SD 57)}

Apart from four annotations with digests of the provisions of Articles 9 (status of guests), 13 (lien), 14 (legal status of widows), and 20 (payment of debt), the copy of the Statutes held in the National Library contains a Latin-Polish glossary of the legal terms of Magdeburg Law. It is divided into two parts, written on two folia - one added to the digest of Ius municipale Magdeburgense and Speculum Saxonum, and the other to the Lübeck Law. The list of entries is fully compatible with Vocabula Iuris Maydemburgensis from Johannes Cervus Tucholiensis' Farrago actionum civilium, published in $1531^{76}$

\subsection{German, Latin, and Polish Glosses (Partly Post-1559;Jagiellonian Library, St. Dr. Cim. 8006-8007)}

In another copy of the Statutes in the Jagiellonian Library, the annotations to the Sachsenspiegel are more than twice as numerous (33) as those added to the Weichbild (15). Only a handful of glosses can be found in the margins of the Lübeck Law and Lehnrecht, and there are very few of them on the pages of Master Raymundus' Summa legum (f. XIII). Although they are in various hands, a great majority of the annotations can be attributed to just two hands. The German glosses are in hand A. They accompany the Sachsenspiegel and the Lübeck Law; their author, not unlike the Latin glossator, is convinced of the importance of a 'bemerkig' (i.e. note, observation). The Latin glosses are in hand B. They can be found in the Weichbild and other key texts of German law in taski's collection. Their sole function is usually to draw attention to a given provision and its importance (that signalling function seems to exhaust the meaning of the glossator's favourite words, nota and notandum). Only two entries are of interest. One, at Article 2, introduces a Polish equivalent of 'revenditor' in 'Penesticus id est revenditor, przekopien' (f. CLXXVII), and the other, at Article 57, 'De iudicio apprehensi', refers the reader to what the Sachsenspiegel has to say about manifestum factum (i.e. a situation when the offender is caught red-handed [super libro 2 folio $C C X X]$ ). Meanwhile, a reference placed next to the provision 'De facto manifesto' in the Sachsenspiegel (f. CCxx verso) points back to the Weichbild, namely, Res manifesta vide supra primo libro folio CLXXXIIII. Commentator B has made only a few annotations to the Lübeck

76 Johannes Cervus Tucholiensis, Farrago actionum civilium Iuris Maydeburgensis (Cracoviae, 1531), f. 5ov-59r. The user of the copy held in the Kórnik Library (Shelfmark Cim.o.24) expanded the vocabulary list by adding 17 more entries (edition 1535, 110r). 
Law, including this one, about the election of aldermen, Notandum. Quod duo ex uno artifico non eliguntur ad consulatum (f. CCXLIIII verso). He does not say much, yet his selection of themes to be marked as noteworthy seems to indicate a growing interest in institutional norms and legal order.

For annotations of more substantial length, we must go to the volume's originally blank pages and three other places in the Sachsenspiegel, two at the beginning of the Landrecht $t^{77}$ and one in the Lehnrecht. ${ }^{78}$ They were inscribed in the second half of the 16th century, after 1559, as they include extracts from Bartłomiej Groicki's Porzadek sadów i spraw miejskich prawa majdeburskiego w Koronie Polskiej [The Constitution of Courts and Urban Matters According to Magdeburg Law in the Kingdom of Poland], published that year. A long note on blank pages $287 \mathrm{r}^{79}$ and $287 \mathrm{v}$. is a farrago of themes ranging from inheritance debts, the abolition of the law banning the surviving spouse (in the absence of children) from becoming heir to the deceased's estate, ${ }^{80}$ the definition of

77 1) Sequitur de Jure Provinciali. Privinciale Jus. Które liud się jednego Króletwa albo krainy miendzi zsobą trzymacz postanowili, jako jest prawo ziemskie Polskie stanowi riczerskiemu dane, jako też jest prawo ziemskie saskie, które zowam Speculum Saxonum (f. CXCVIII). ["The land law is that which the people of a Kingdom or a land have decided to hold on to in common: Polish land law has been given to the nobility, and there is also Saxon land law, also known as Speculum Saxonum".]. 2) Jus Saxonum Provinciale Prawo Ziemskie Saskie Które zowyą Speculum Saxonum (f. cxcviII verso).

78 Feudale ius quia. Ius Feudale alias miejskie zakupne prawo, które łacinnicy zowią feudale do rycerskiemu człowiekowi za wojenną służbę bywa dane jakie imienie czasem do żywota, czasem też do potomków tegoż pokolenia, tym sposobem, aby w łączność tego imienia została przy pierwszym własnym panie, a użytkowanie tylko jest przy tym, któremi jest dany, aby stamtąd czynił jaką posługę krolie swego albo jakiemu państwo albo panu onego imienia. (f. CCXLV verso). ["Ius feudale, or urban acquired rights, which the clerks call feudale because it is held with a fee granted to a knight for his military service; its tenure either expires with the tenant's death or is inherited by his offspring in such a way that the ownership continues to be attached to the original overlord, while possession and use is passed on jointly with the obligation to perform knight-service to the king, the state, and the owner of the fee".] This glossa is similar to the fragments in Bartłomiej Groicki and Paweł Szczerbic's works: Bartłomiej Groicki, Porzadek sadów $i$ spraw miejskich prawa majdeburskiego w Koronie Polskiej [The Constitution of Courts and Urban Matters According to Magdeburg Law in the Kingdom of Poland], (Biblioteka Dawnych Polskich Pisarzy-Prawników) 1, ed. Karol Koranyi (Warszawa, 1953), p. 5; SzIM Article 1 No. 17.

79 There, of course, with another hand, a provenance note - Michał, Kazimierz i Prochna Czepielowscy, 22 I 165o. There, too, a provenance note, in a different hand to be sure, dated 22 January 1659, naming Michał, Kazimierz, and Prochna Czepielowscy as owners of this book.

8o Dziedziców kiedy nie masz, mąsz zonam po sobie spa[dek] biorą, mimo skarb królewski. ["If there are no heirs, the estate falls to the surviving spouse, save the exchequer's portion".] 
wergild, ${ }^{81}$ the definition of szelag (shilling), ${ }^{82}$ a diagram showing the branches of the law (copied from Groicki's Constitution), ${ }^{83}$ and a description of the principles of law and justice (praecepta iuris), also copied from Groicki's treatise. ${ }^{84}$

The main conclusion from the analysis of a number of the surviving copies Laski's Statutes (1506) is that the key texts of the Saxon-Magdeburg Law continued to be read and used after 1535, that is, after the publication of a new, revised edition of those texts by Mikołaj Jaskier. The users of the Statutes continued to annotate them in the vein of medieval glossators. The new additions came primarily from the works of Johannes Cervus of Tuchola and Bartłomiej Groicki, while Jaskier's edition of the Weichbild became the new standard text of that old source. Interestingly, in some of the copies of the Statues, the annotations are inscribed exclusively in the margins of the key texts of municipal law and Master Raymundus' Summa legum. In other copies, the gloss is concentrated exclusively around key texts of land law or on the initial leaves of a manuscript. ${ }^{85}$ This distribution of the supplementary material is undoubtedly

81 Wergeld co jest. Cały wergeld czyni dwadzieścia złotych reńskich w monecie, które przegodzą ku wadzę dwój, jest to złotych polskich na monetę. (f. 287). ["What is wergild. The whole wergild amounts to twenty Rhinish złotys in coins, or the equivalent of its weight, twice as many Polish złotys for coin".]

82 Solidus co jest. Szelągów trzydzieści wodlia rachunku czynią groszy 20. Szelągów sześćdziesiąt czynią groszy sterdzieści. Wina burgrabska szelągów ośm czynią groszy pięć. Szeląg wina wójtowska. (f. 287) ["What is a solidus. Thirty shillings are made up of 20 groszy. Sixty shillings are made up of 40 groszy. The Burgraf's fine of eight shillings equals five groszy. The wójt's fine is one shilling".]

83 Ius est aequm et iniqui cognitio. Summa wszytkich praw wedle rozdziału wyżej opisanego w porządku prawnym. ["The summa of all laws according to the chapter described above in the order of the law".] [chart: division of law into God, natural and human, with further division of human law into spiritual and secular, dividing into earthly, war, purchasing and urban] (Groicki, Porzadek, p. 7).

84 Iuris descriptio. Prawo tedy jest nauka, która widzie ku wszelkiej poczciwości, a odwodzi od każdej nieprawości, aby przez taką naukę i skutek jej zuchwalstwo ludzi hamowane było, a między dobremi niewinność w bezpieczeństwie trwała. Summa praw wszytkich. Tej nauki ta summa jest, aby każdy poczciwie żył, bliźniego nie obrażał, każdemu co jest jego dał. Albo prawo tak się inszym sposobem opisuje: jest postanowienie sprawiedliwości od zwierzchniego pana, na poddanie swoje, ku chwale Bożej, ku poczciwemu życiu, a zachowaniu pokoju pospolitego. ["The law is therefore a knowledge which leads to all kinds of respectability and dissuades from every dishonesty so that by that science and its effects people's presumption was tempered and innocence could safely flourish among the good. The summa of all laws. The sum of all this knowledge [allows] everybody to live honestly, to avoid offending his neighbor and to give everyone else his due. Or, there is a different way of describing what law is: it is a command of justice from the overlord, given to those who submit, for the greater glory of God, to achieve an honest life and for the keeping of the peace".] (Groicki, Porzadek, p. 2).

85 Biblioteka Narodowa, stare druki Shelfmark No. 88, 211, 335, 350 and 735 . 
connected with the functioning and the uses of Łaski's book. Mikołaj Jaskier's Ius Municipale were published almost 30 years after the Statutes, a sufficiently length time for the text of the latter to be widely adopted, and yet the old texts were not thrown out (cf. Chapter 3, Section 6.). Jaskier's new edition gained ground fast, and its impact can be felt in the treatises on municipal law written by Johannes Cervus of Tuchola and Jan Kirstein Cerasinus. ${ }^{86}$ The reception of Jaskier's updated version in the circles of legal practitioners was greatly accelerated after 1559, that is, the publication of its Polish translation by Bartłomiej Groicki.

King Zygmunt I wanted Jaskier's work to become the sole official book of the Saxon-Magdeburg Law, but, as might be expected, old habits were not to be stamped out overnight. ${ }^{87}$ Lawyers continued to make glosses in the margins of their copies of the Statutes after 1539 - and even after 1559. The provisions of urban law from Łaski's Commune incliti were read and commented on long after the publication of Jaskier's Ius Municipalis in $1535 .{ }^{88}$

Habent sua fata leges - this paraphrase of a well-known maxim is in no way an inadequate description of the history of the Latin texts of the Weichbild. Copyists and users not only made alterations in its main text, but also supplemented it with a variety of subsidiary annotations, marks, and glosses, both

86 Karol Koranyi, “Johannes Cervus Tucholiensis i jego dzieła (z dziejów praw obcych i literatury prawniczej w Polsce)" [Johannes Cervus Tucholiensis and His Work (Chapters from the History of Foreign Laws and Legal Literature in Poland)], Przewodnik Historyczno-Prawny 1 (1930), pp. 22 and 28; Bojarski, Jan Jelonek Cervus z Tucholi, p. 64; Lesław Pauli,Jan Kirstein Cerasinus (1507-1561). Krakowski prawnik doby Odrodzenia. Studium z dziejów praw obcych i literatury prawniczej w Polsce [Jan Kirstein Cerasinus (1507-1561): A Cracow Jurist of the Renaissance. A Study in the History of Foreign Laws and Legal Literature in Poland] (Kraków, 1961), pp. 6-7; Lesław Pauli, "Die polnische Literatur des Magdeburger Rechts im 16. Jahrhundert", in: Studien zur Geschichte des sächsich-magdeburgischen Rechts in Deutschland und Polen, eds. Dietmar Willoweit and Winfried Schich, Rechtshistorische Reihe 10 (Frankfurt am Main, 1980), pp. 150-157.

87 Cf. "Law Books During the Transition from Late-Medieval to Early-Modern Legal Scholarship", in: The Formation and Transmission of Western Legal Culture. 150 Books that Made the Law in the Age of Printing, Serge Dauchy, Georges Martyn, Anthony Musson, Heikki Pihlajamäki, Alain Wijffels, eds., coop. Naoko Seriu (Studies in the History of Law and Justice) 7, series eds. Georges Martyn, Mortimer Sellers (New York - Berlin Heidelberg, 2016), p. 17.

88 Whether the inclusion of a glossed Weichbild and a glossed Sachsenspiegel was intended as a compensation for the exclusion of the ortyle is a point that still needs to be examined. 
marginal and interlinear. They had different functions, yet the reasons for their presence were always pragmatic. Their authors used them to amend mistakes in the main text, set up cross-references within the text, and compile indices and digests. The sign of the pointing hand, or manicule, drew attention to regulations that were deemed more important than others. Various kinds of notes sought to help the reader gain a better understanding of the text. A careful analysis of the glosses in the Silesian-Małopolska compilation has shown that amendations and annotations were most common in the manuscripts of versio Sandomiriensis. These texts were also dotted with excerpts from the versio Cracoviensis, which superseded an earlier translation by Konrad of Sandomierz (the Działyńscy Codex I) and by pulling in numerous annexes, mostly ortyle, or judgments of the courts of Magdeburg Law. This was the formula of the Żegota Pauli's Ms. Another type of supplement was a bilingual vocabulary list. To compile such a list, the scribes usually drew on a source like the glossary in Ms Dział. I. This was replicated in the Weichbild of that manuscript and in Tomasz of Bydgoszcz's ms. The authors of those manuscripts also brought in regulae iuris, drawn from Boniface viII's Liber Sextus, to balance the detailed and narrowly focused provisions of the Magdeburg Law with more general legal maxims. There are also manuscripts which have no glosses at all; we can only guess as to the reasons why they remained in that condition.

The Działyńscy Codex I and Tomasz of Bydgoszcz's Ms (BN 3068) have a full range of supplements. In MS BN 3068, the regulae iuris appear both in the main text (in red ink) and in the margin. The latter are written in script which may well belong to a different hand. It is clear that they are written with a different type of utensil than the main text. A comparative analysis of the Polish terms and regulae iuris in both texts indicates that Tomasz of Bydgoszcz must have used the Działyńscy Codex I. This therefore makes it his third source, alongside Łaski's Statutes and a text close to the Baworowscy ms. The argument that Tomasz of Bydgoszcz relied on Ms Dział. I is based on the following observations. The list of regulae iuris in the gloss of the Działyńscy Codex I is longer than the one in MS BN 3068. Tomasz copied the list, but left some maxims out. He also added to his manuscript a list of Latin legal terms with their Polish equivalents. The Polish terms come from the glossary Vocabula iuris Meydeburgensis in Ms Dział. I, but the number of Polish words in BN 3068 is greater than in Tomasz's source. It looks as if after copying the words from the Działyńscy Codex I glossary, he decided to add some more himself. On one occasion, however, he took a word not from the Vocabula glossary, but directly from the Działyńscy Codex I gloss. The former lists the word przegabanÿe, whereas the gloss of MS Dział. I and MS BN 3068 have nagabanÿe. 
The presence of regulations of the Chełmno Law in the Działyńscy Codex IV have been interpreted as an indication that the provenance of that manuscript must be connected with towns of Northern Poland, that is, the area where the Chełmno Law was common. However, manuscripts of Chełmno Law were also available in Cracow, and given the collation of the text of the Działyńscy Codex IV with the Wawel Ms, the Cracow provenance of Dział. IV can no longer be ruled out.

In a number of cases, the collation of manuscripts led to the creation of miscellaneous codices like the Częstochowa Ms, the Kielce Ms, and the Leipzig Ms. The Weichbild in Łaski's Statutes belongs to the category of complex compilations. Its main text had two parents, the Sandomierz version and the Cracow version; later, it grew, and shed, all kinds of annotations and supplements - rubrics, notes, indexes, digests, and vocabulary lists of legal terms. The identification of these annotations' and supplements' sources made it possible to conclude that glosses continued to be produced after 1535, and to a lesser extent even after 1559. In all, copies of Łaski's Statutes remained in use in urban legal practice even after the loss of its official status after the publication of a thoroughly new edition of the Weichbild and other sources of Magdeburg Law by Mikołaj Jaskier in 1535 .

This analysis of the annotations and commentaries found in the margins of the Weichbild demonstrates that its use in legal practice was absolutely common. The text of the Weichbild was regularly analysed and annotated. Its readers compared their copies, marked out divergences, and inserted explanations, Polish equivalents, and excerpts from other normative acts. All that work could have no other aim than to help other members of the legal community to use their prime law book. 


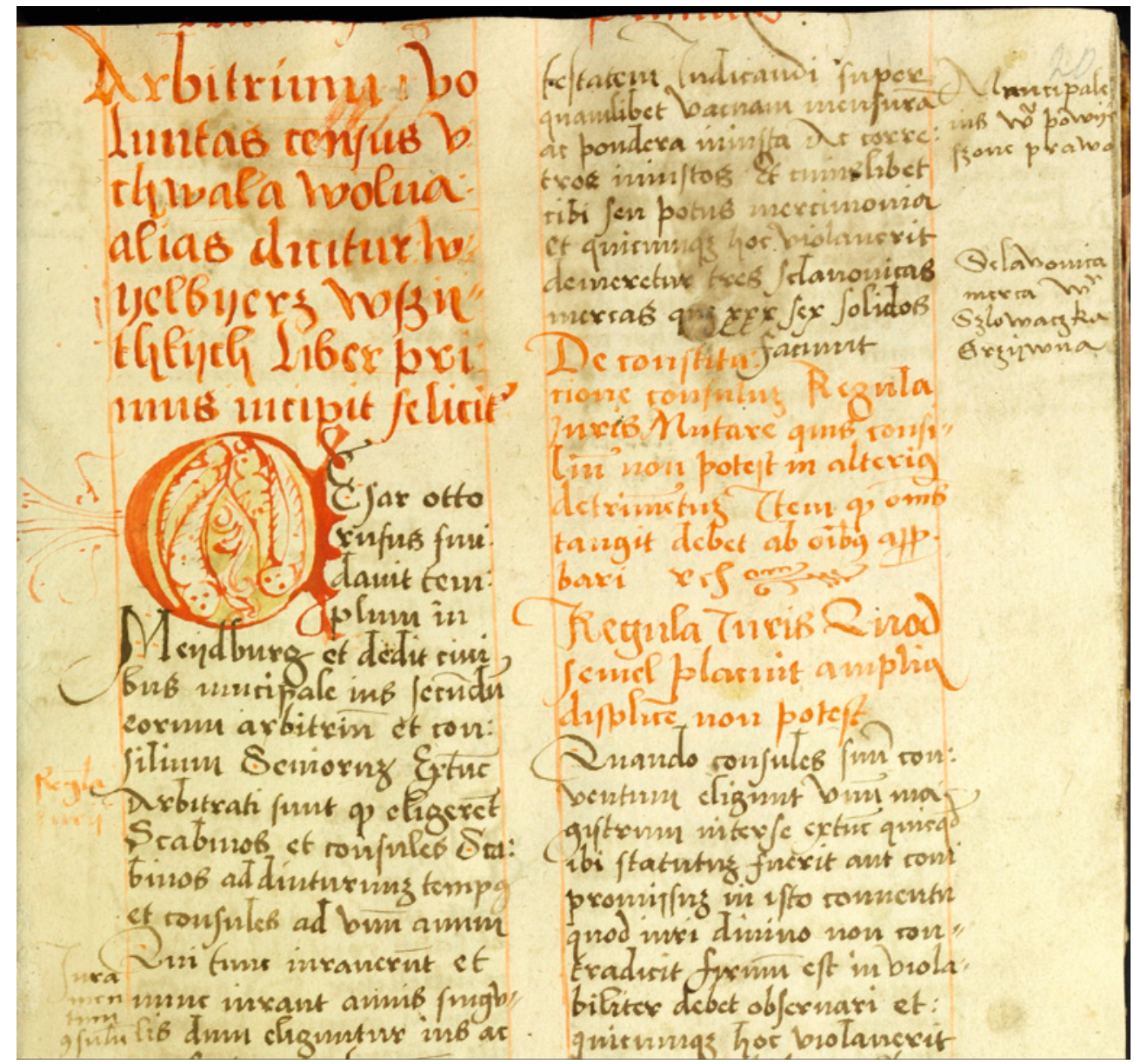

рното 9 Tomasz of Bydgoszcz's manuscript, The National Library in Warsaw, Shelfmark 3 o68 III, f. 20 or 


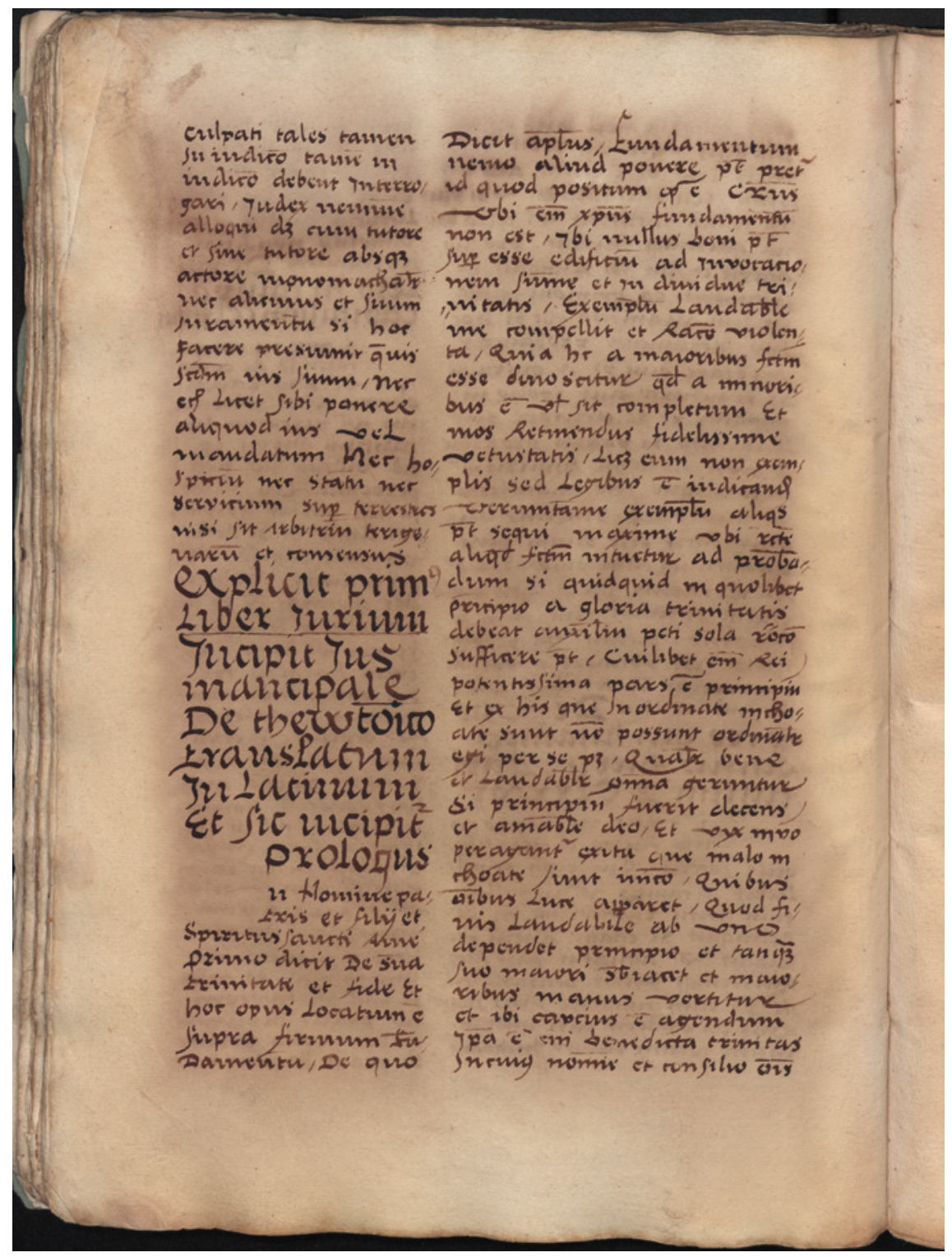

Рното 10 Marcin Zabowski's manuscript, The National Library in Warsaw, Shelfmark воZ 9 o, f. $45 \mathrm{v}$ 